\title{
I. Mance*
}

\section{MODELIRANJE SUSTAVA SMANJENJA OZLJEDA NA RADU U HRVATSKOJ POŠTI d.d.}

UDK 656.8:614.8](497.5)

PRIMLJENO: 22.11.2018.

PRIHVAĆENO: 29.5.2019.

Ovo djelo je dano na korištenje pod Creative

Commons Attribution 4.0 International License

SAŽETAK: Cilj ovog rada je razrada, modeliranje i implementacija sustava smanjenja ozljeda na radu u Hrvatskoj pošti. U radu se prikazuje plan (gantogram) modeliranja i uvođenja predmetnog sustava u poslovanje Hrvatske pošte, da bi se metodom modeliranja teoretski razradio sam sustav ONR_min. Nadalje se analizira njegova primjenjivost u samoj analizi ozljeda na radu Hrvatske pošte prije njegovog uvođenja na početku 2014. god. te kontinuirano njegovom primjenom do kraja 2017. godine. Kroz nekoliko studija slučaja prikazuju se stvarni učinci primjene modela, da bi se zaključno prikazali financijski pokazatelji i uštede koje su ostvarene primjenom predmetnog modela.

Ključne riječi: smanjenje ozljeda na radu, model ONR_min, Hrvatska pošta, zaštita na radu

\section{UVOD}

Za sada najstariji spomen Pošte u Hrvatskoj datira iz jedne glagoljske listine napisane 13. ožujka 1527. god. Donosi ga Ivan Kukuljević Sakcinski u Acta Croatica (Hrvatski spomenici, Listine hrvatske), gdje Franjo Jožefić, senjski biskup (slika 1.), piše knezu Krištoforu Frankapanu i uvjerava ga u svojoj odanosti. Biskup Jožefić tako kazuje: „Tulikoi prvo sam bil pisal v. m. (vašoj milosti, op. IM) iz Benetak (iz Venecije, op. IM), i poslal na poštu listi u Novi-Grad, i znam; da su predani Ivanu Bisrakoviću ki mi (j)e junake i kon(j)e nepodobno izagnal van. ${ }^{\prime 1}$

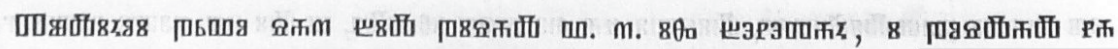

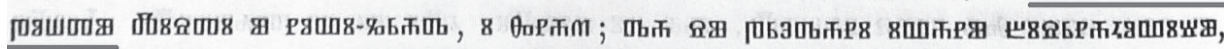

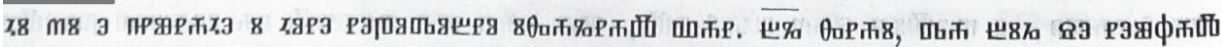

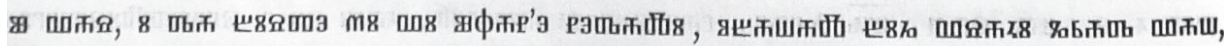

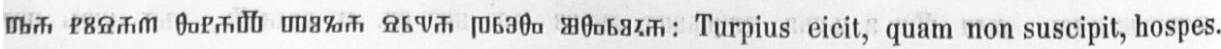

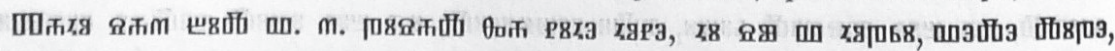

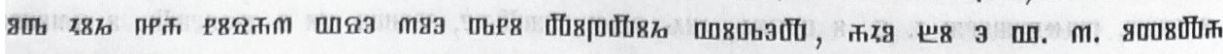

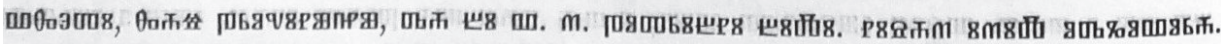

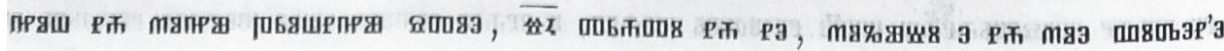

Slika 1. Prvi spomen Pošte, glagoljska listina iz 13.3.1527. god.

Figure 1. First mention of postal service, Glagolitic document from 13th March, 1527

*Mr. sc. Ivan Mance, (ivan.mance@posta.hr), HP - Hrvatska pošta d.d., Jurišićeva 13, 10000 Zagreb.
'Sakcinski, 1863., str. 220. 
U Hrvatskoj je 11.8.1848. bila osnovana prva nacionalna poštanska uprava sa sjedištem u Zagrebu - Vrhovno hrvatsko-slavonsko upraviteljstvo pošta ${ }^{2}$. U razdoblju Kraljevine SHS odnosno Kraljevine Jugoslavije pošta je bila pod upravom različitih ministarstava (neko vrijeme posebnoga Ministarstva pošta, telegrafa i telefona), a u socijalističkoj Jugoslaviji Direkcija Pošte, telegrafa i telefona (PTT) bila je dio Zajednice jugoslavenskog PTT-a. U modernoj Republici Hrvatskoj, Sabor je 10. 10. 1990. utemeljio javno poduzeće Hrvatska pošta i telekomunikacije (HPT). Hrvatska pošta kao samostalna tvrtka nastala je tek 1999. god. nakon što se razdvojila iz "HPT" u sadašnju Hrvatsku poštu d.d. i HT-Hrvatski telekom.

Ozljedom na radu (dalje: ONR) prema važećem zakonodavstvu ${ }^{3}$ smatra se svaka ozljeda izazvana neposrednim i kratkotrajnim mehaničkim, fizikalnim ili kemijskim djelovanjem te ozljeda prouzročena naglim promjenama položaja tijela, iznenadnim opterećenjem tijela ili drugim promjenama fiziološkog stanja organizma, ako je uzročno u vezi s obavljanjem poslova, odnosno ako je uzročno povezana s radom. Pojavnost ONR do sada je istraživana s različitih stajališta: u pojedinim granama industrije ili djelatnosti, kao učestalost ozljeđivanja pojedinih dijelova tijela, kao aktivnosti koje se provode u svrhu smanjenja ozljeda na radu i sl. Jedno od prvih istraživanja uopće u vezi s bolestima i ozljedama na radu objavio je W.G. Thompson još 1914. godine. U njegovoj opsežnoj knjizi ${ }^{4}$ prikazao je razloge nastanka, simptome, liječenje i prevenciju ozljeda i bolesti na radu u SAD-u. Autor u knjizi vjeruje u napredak zaštite radnika i smanjenje ozljeda i bolesti na radu, no kao ključnu prepreku ističe neznanje. Tako navodi primjer vladinog dužnosnika koji doživljava ozljedu na radu „na putu na posao" i očekuje liječenje po toj ozljedi. Problem je što iz neznanja odabire na posao ići jašući na konju (koji ga jedne prilike izbacuje sa sebe, pri čemu se dužnosnik ozlijedio), umjesto vozeći se u dodijeljenom mu službenom automobilu.

U jednom od prvih članaka o ONR objavljenom kod nas 1950. godine analiziraju se uzroci

\footnotetext{
${ }^{2}$ http://www.enciklopedija.hr/natuknica.aspx?id=49722

${ }^{3}$ https://www.zakon.hr/z/192/Zakon-o-obveznom-zdravstvenomosiguranju

${ }^{4}$ Thompson, 1914
}

ozljeda električnom strujom u Švedskoj u razdoblju od 1930. do 1944. god. ${ }^{5}$ Autorica zaključuje kako ozljede električnom strujom vrlo često završavaju smrtno ili uzrokuju veliki postotak invaliditeta te apelira da se učini sve sa stajališta "zaštite na radu" kako bi se predmetne ozljede smanjile.

Godine 1953. Marijan Košiček, naš poznati neuropsihijatar i seksolog, objavljuje rad u kojem je istaknuo kako neuroze od kojih boluju radnici mogu za posljedicu imati češće ozljeđivanje na radu te ističe: "Razumljivo je, da u takovom momentu izmicanja radnog procesa iz centra radnikova duševnog vidnog polja zatajuju neobično fini koordinacioni mehanizmi u radnikovom živčanom sistemu. Ako čovjek radi na nekom opasnom stroju ili vrši bilo kakav posao gdje postoji mogućnost ozljeđivanja, vrlo je vjerojatno da će se ozlijediti, čim se zbog poremećene živčane koordinacije samo malo promijene njegove kretnje, te postanu netočne i neprikladne. Zar da u takvom slučaju okrivimo stroj?"6 Dr. Košiček iznosi i dvije studije slučaja kojima potkrepljuje svoja promišljanja te zaključuje kako u radnom procesu možemo samo tražiti povode za izbijanje neuroze (i njome povećanog rizika od ozljeda) na očitiji način, no kako liječenje neuroza i s njima povezanih ozljeda na radu učinkovito možemo provoditi isključivo u djetinjstvu. Ovime dr. Košiček vrlo vizionarski upućuje na moderne zaključke i istraživanja 21. stoljeća koja potvrđuju da je važno djecu od vrtićke dobi učiti obavljati sve postupke i aktivnosti na siguran način.

Nadalje se kod nas objavljuju istraživanja oko ozljeda na radu po različitim granama djelatnosti poput analize ozljeda na radu u poljoprivredi ${ }^{7}$ 1984. god., analize ozljeda na radu u graditeljstvu Karlovačke županije ${ }^{8}$ 2003. god., analize ozljeda na radu vatrogasaca ${ }^{9}$ 2013. god., analiza ubodnih ozljeda medicinskog osoblja u operacijskim dvoranama ${ }^{10} 2016$. god. i sl.

Isto tako hvale su vrijedna opsežnija istraživanja ozljeda na radu provedena za cijele države. Godine 2010. poštovani kolege Pavlič i Markič

\footnotetext{
${ }^{5}$ Nyström, 1950.

${ }^{6}$ Košiček, 1953.

${ }^{7}$ Bradić \& sur., 1984.

${ }^{8}$ Vučinić \& Ivančić, 2003.

${ }^{9}$ Bognolo \& Ferhatović, 2013.

${ }^{10}$ Kozina, 2016.
} 
objavili su istraživanje ozljeda na radu u Republici Sloveniji ${ }^{11}$ od 1960. do 2008. god. Uz to što su u tom radu izradili cjeloviti kronološki pregled broja ozljeda na radu u Republici Sloveniji za razdoblje od gotovo 50 godina, utvrdili su kako su se u tom razdoblju promijenile kako metodologije sakupljanja podataka o ozljedama na radu tako i njihovo evidentiranje.

Istraživanje ozljeda na radu u Republici Hrvatskoj u promatranom razdoblju od 1996. do 2016. god. ${ }^{12}$ objavljeno je 2018. U vrlo kvalitetnoj statističkoj obradi podataka autori dijelom potvrđuju postavljenu hipotezu prema kojoj postoji statistički značajna korelacija između trenda zapošljavanja u realnom sektoru (proizvodna industrija, građevinarstvo i distribucija) te ukupnog broja ozljeda na radu u Republici Hrvatskoj. Rezultati istraživanja na razini država upućivali su na izradu preventivnih programa zaštite na radu.

U stranim zemljama provodi se cijeli niz istraživanja povezanih s ozljedama na radu, a ovdje se navodi vrlo zanimljivo novije istraživanje u vezi sa stopom ozljeđivanja na radu novopridošlih imigranata u Kanadu. Tako autori u svojem istraživanju ${ }^{13}$ problematiziraju mogućnost kvalitetne profesionalne evaluacije imigranata $\mathrm{s}$ obzirom na jezične barijere, problem usklađenosti njihovih diploma i radnog iskustva te nedostatak poslovnih mreža u kojima bi se potvrde o njihovim radnim iskustvima mogle provjeriti. To, između cijelog niza drugih okolnosti, dovodi do spoznaje kako se imigranti ozljeđuju nekoliko puta više od domicilnih kanadskih radnika, zaključuju autori. Ovo je iznimno zanimljiv podatak ako se u obzir uzmu dnevno-politički trendovi EU-a prema kojima su poslovne migracije, zbog nedostatka radne snage u Europi, čak i dobrodošle. Zaista se može postaviti pitanje koliko je priča s poslovnim migracijama uopće u konačnici svrsishodna ako se u obzir uzmu, između ostalog, i problemi s povećanim ozljeđivanjem na radu migranata.

Gotovo sva istraživanja u vezi s ozljeđivanjem na radu, kako u nas tako i vani, prikazuju trendove ozljeda ili trendove u promatranom razdoblju te sintetiziraju njihove izvore i uzroke nastanka.

\footnotetext{
${ }^{11}$ Pavlič \& Markič, 2010.

${ }^{12}$ Pupavac \& sur., 2018.

${ }^{13}$ Yanar \& sur., 2018.
}

No, jako je malo istraživanja povezanih s ozljedama na radu koja se bave metodologijom prevencije ozljeda ili konkretnim prijedlozima njihovog smanjenja. Tako Mance i suradnici ${ }^{14}$ 2013. god. objavljuju istraživanje ozljeda na radu nastalih zbog ugriza pasa u djelatnosti univerzalnih poštanskih usluga. $U$ ovom istraživanju se uz samu analitiku ozljeda donose i konkretne te stvarnom primjenom potvrđene metode smanjenja ozljeda nastalih zbog ugriza pasa. Upravo u tom kontekstu jest i opravdanost ovog istraživanja, jer će se u njemu pokušati sintetizirati i prikazati potpuno živ i operativan sustav smanjenja ozljeda na radu koji se provodi u Hrvatskoj pošti d.d. i daje konkretne rezultate u trendu smanjenja ozljeda na radu.

\section{METODOLOGIJA}

Organizacijski sustav smanjenja ozljeda na radu (u daljnjem tekstu radnog naziva: ONR_min) uveden je u Hrvatsku poštu d.d. početkom 2014. god. Cilj ovog istraživanja je izrada organizacijskog modela ONR_min. Stoga je potrebno obraditi i analizirati sve ozljede na radu prije uvođenja ONR_min i nakon njega. Za vremenski okvir postavlja se sljedeće razdoblje analize ozljeda na radu: od početka 2008. do kraja 2017. god., uz referentnu točku na početku 2014. god. kada je ONR_min i operativno uveden u poslovanje. Nadalje je cilj istraživanja kroz analizu nekoliko stvarnih ozljeda radnika na radu (studij slučaja) dokazati ili opovrgnuti učinkovitost modela ONR_min.

Iz ciljeva istraživanja proizlazi i hipoteza istraživanja: Primjenom modela ONR_min moguće je kvalitetnije utjecati na smanjenje ozljeda na radu, od primjene konvencionalnih metoda zaštite na radu.

Za dokazivanje ili opovrgavanje hipoteze istraživanja koristit će se sljedeća metodologija:

- Deskriptivna metoda uz pomoć koje će se opisivati i analizirati sve ozljede na radu u Hrvatskoj pošti d.d., za cjelovito razdoblje analize 2008.- 2017. god.

- Metoda prikupljanja i analize podataka kojom će se prikupiti i analizirati podaci o

${ }^{14}$ Mance \& sur., 2015. 
ozljedama na radu u Hrvatskoj pošti d.d., za cjelovito razdoblje analize 2008.- 2017. god.

- Metoda modeliranja - dijagram toka, BPMN v2.0 ${ }^{15}$ i druge metode kojima će se modelirati, opisati i prikazati sam model ONR_min.

- Statističke metode izračunavane uz pomoć tabličnog kalkulatora MS Excel『 kojima će se statistički analizirati prikazani podaci o ozljedama na radu.

- Studij slučaja - kojim će se prikazati nekoliko stvarnih situacija ozljeđivanja na radu nakon uvođenja sustava ONR_min, a što će pomoći u analizi njegove uspješnosti ili neuspješnosti.

\section{REZULTATI}

Hrvatska pošta d.d. krajem 2012. god. prema važećim podacima Hrvatskog zavoda za zdravstveno osiguranje ${ }^{16}$ bila je druga kompanija u Republici Hrvatskoj po apsolutnom, odnosno ukupnom broju ozljeda na radu. Prema tim podacima, ispred Pošte bili su jedino klinički bolnički centri Zagreb, Split, Rijeka i Osijek - ali sveukupno. Tako KBC Zagreb broji oko 5.500 zaposlenih, KBC Osijek oko 3.000 zaposlenih, KBC Rijeka oko 3.000 zaposlenih te KBC Split oko 3.200 zaposlenih. To sveukupno iznosi oko 14.700 zaposlenih, dok je Hrvatska pošta u to vrijeme imala oko 10.700 zaposlenih, a što je oko $37 \%$ manje radnika. Ako se tome pridoda vrlo načelna usporedba razine opasnosti, štetnosti i napora u smislu zaštite na radu, a koji se mogu očekivati u kliničkim bolničkim centrima u Republici Hrvatskoj (ozljede gležnjeva zbog nepravilne obuće, napadi na medicinsko osoblje, izloženost raznim tipovima zaraza, rane dobivene u operacijskim salama itd.) s onima koje se mogu očekivati u djelatnosti poštanskih usluga (prometne ozljede, razbojstva i prepadi, ugrizi pasa itd.) - nikako se ne može tvrditi da je njihova razina veća u djelatnosti Pošta.

Jasno da bi za preciznu usporedbu trebalo proanalizirati Procjene opasnosti iz obje djelat-

\footnotetext{
${ }^{15} \mathrm{https}$ //www.omg.org/spec/BPMN/2.0/

${ }^{16}$ Grupa autora, 2013.
}

nosti, no evidentno je kako opravdanosti za takav broj ozljeda na radu u Pošti, niti s obzirom na ukupan broj radnika, niti s obzirom na očekivanu razinu opasnosti, štetnosti i napora - nema. Isto tako 2012. god. prema tada važećem Nacionalnom programu zaštite zdravlja i sigurnosti na radu za razdoblje 2009. - 2013. god. ${ }^{17}$ izrijekom se navodi mogućnost uvođenja sustava bonus-malus, kojim bi se smanjivale stope doprinosa onim poslodavcima koji ulažu u zaštitu i obrnuto. Drugim riječima, manji doprinos za slučaj ozljede na radu plaćali bi poslodavci s manjom stopom ozljeda na radu u djelatnosti i obrnuto. Od početka 2019. god. sustav bonus-malus je definitivno ukinut i kao opcija jer je ukinuta i stopa doprinosa od $0,5 \%$ za slučaj ozljede na radu. Stoga još nije poznato na koji način država misli nagrađivati/kažnjavati poslodavce koji (ne) preveniraju ozljeđivanje na radu.

Kako je Hrvatska pošta te 2012. god. iz Hrvatskog zavoda za zdravstveno osiguranje opetovano upozoravana na alarmantno stanje ozljeda na radu $^{18}$, te kako bi povećanje doprinosa opcijom uvođenja sustava bonus-malus na razini države značilo milijunsko povećanje troškova doprinosa, bilo je nužno i opravdano krenuti u dizajniranje cjelovitog organizacijskog sustava smanjenja ozljeda na radu - ovdje nazvanog ONR_min. Početkom 2013. god. Poslodavcu je prezentiran gorući problem sa stanjem ozljeda na radu u Pošti, te je Služba zaštite na radu nakon dobivenog zelenog svjetla od strane Poslodavca cijelu 2013. god. radila na pripremnim radnjama i realizaciji projekta ONR_min, a što se prikazuje sljedećim gantogramom (slika 2).

Priprema projekta i njegova implementacija trajala je približno godinu dana. Kako se govori o poslovnom sustavu od 10.000 radnika, koji rade na preko 1.000 lokacija u Republici Hrvatskoj, nije nerealno očekivati da će projekt koji ulazi u svaki organizacijski segment i dotiče svakog radnika kompanije trajati izvjesno vrijeme. Tako se projekt ONR_min realizirao u 14 faza koje će se ovdje ukratko opisati:

\footnotetext{
${ }^{17}$ Nacionalni program zaštite zdravlja i sigurnosti na radu za razdoblje 2009. - 2013. god., 2008.

${ }^{18}$ Analiza stope ONR za 2012. god. pokazala je kako je prosječna stopa ONR u poštanskim i kurirskim djelatnostima u RH iznosila 15,31, dok je ta stopa u HP-u iznosila 41,97 - a što je 2,74 puta iznad prosjeka.
} 
1. Faza - Terenska analiza. Započela je 1. veljače 2013. god. sa 14 dana očekivanog trajanja. Radilo se o jasno definiranom nalogu voditelja Službe zaštite na radu prema svim stručnjacima zaštite na radu (ZNR); (Služba zaštite na radu u Pošti broji 26 stručnjaka ZNR dislociranih po cijeloj državi i zasigurno je jedna od kadrovski najvećih u Republici Hrvatskoj) da načelno proanaliziraju stanje i okolnosti oko nastanka ozljeda na radu na području za koje su zaduženi. Na temelju te iskustvene analize bilo je potrebno dati nekoliko prijedloga organizacijskih promjena i konkretnih aktivnosti koje bi po njihovom iskustvu i očekivanju pomogle u smanjenju ozljeda na radu na njihovom području. Promišljanja su očekivano bila različita jer su i iskustva, ali i sam pristup problematici ozljeda na radu različiti, no svakako su pomogla u definiranju inačica budućeg modela ONR_min.

2. Faza - Stručnjaci ZNR. Započela je 15. veljače 2013. god. sa 5 dana očekivanog trajanja. U ovoj fazi stručnjaci ZNR bili su upoznati na sastanku s idejom izrade modela, očekivanim rezultatima koje bi uvođenje modela trebalo polučiti kao i s ovdje opisanim gantogramom realizacije projekta.
3. Faza - Prikupljanje prijedloga. Započela je 20. veljače 2013. god. sa 10 dana očekivanog trajanja. Nakon što su stručnjaci ZNR proanalizirali stanje s ozljedama svaki na svojem području, te potom bili upoznati s konkretnim planom oko implementacije modela, dobili su zadatak dati konkretne inačice i elemente budućeg modela. I ovdje su prijedlozi bili razni, no korist ove faze je višestruka: nekolicina prijedloga bila je vrlo primjenjiva, a i sami stručnjaci ZNR uključeni su od samog početka modeliranja, kao upravo oni koji će budući sustav svakodnevno i provoditi operativno na terenu.

4. Faza - Obrada i analiza. Započela je 3. ožujka 2013. god. sa 28 dana očekivanog trajanja. U ovoj fazi sumirani su, analizirani i definirani svi prikupljeni podaci sa ciljem izlučivanja ključnih elemenata budućeg sustava ONR_min.

5. Faza - Teorijsko modeliranje. Započela je 1. travnja 2013. god. sa 30 dana očekivanog trajanja. $U$ ovoj fazi izvršeno je teorijsko modeliranje sustava uz pomoć metoda i alata modeliranja, a koje će se detaljnije opisati u poglavlju "Modeliranje sustava ONR_min".

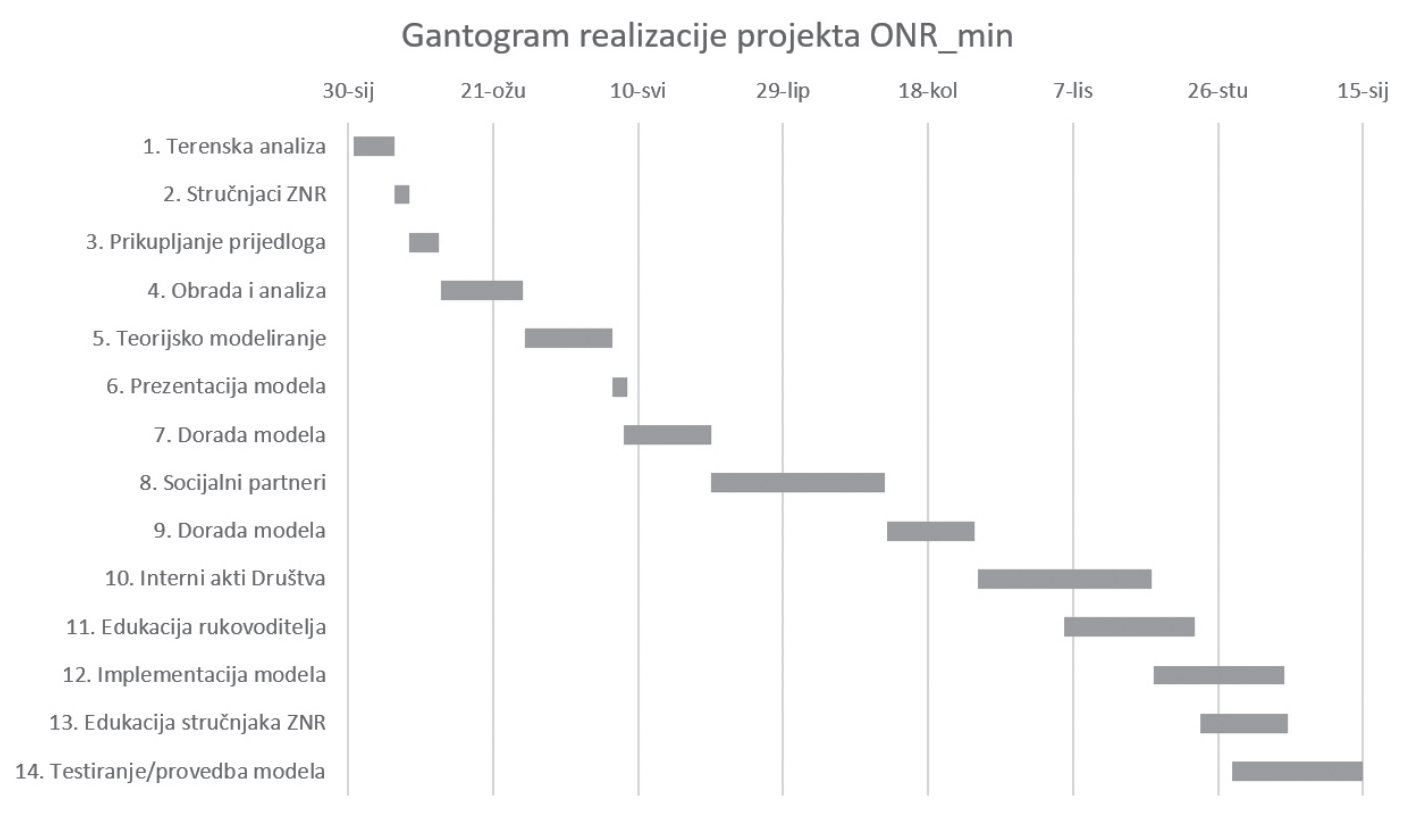

Slika 2. Gantogram realizacije projekta ONR_min

Figure 2. Gantt chart for ONR_min project realisation 
6. Faza - Prezentacija modela. Započela je 1. svibnja 2013. god. sa 5 dana očekivanog trajanja. Nakon završenog teorijskog modeliranja sustava, stručnjaci ZNR su u ovoj fazi bili upoznati sa samim modelom koji im je prezentiran sa svim značajkama i dijelovima procesa. Prikupljena su i promišljanja stručnjaka ZNR u vezi s njihovim poimanjem operativne izvedivosti pojedinih elemenata sustava na terenu.

7. Faza - Dorada modela. Započela je 5. svibnja 2013. god. sa 30 dana očekivanog trajanja. $U$ ovoj fazi model je teorijski dorađen $u$ vezi $\mathrm{s}$ dobivenim promišljanjem stručnjaka ZNR oko njegove operativne izvodivosti. Izvršena je i teorijska simulacija modela na nekoliko slučajno odabranih prijašnjih ozljeda na radu.

8. Faza - Socijalni partneri. Započela je 4. lipnja 2013. god. sa 60 dana očekivanog trajanja. S obzirom na obveze Poslodavca u vezi sa Zakonom o radu i Zakonom o zaštiti na radu, bilo je potrebno radničke predstavnike upoznati s planiranim promjenama u području zaštite na radu. Nevezano uz zakonske odredbe, Hrvatska pošta može se pohvaliti iskustvima dobre prakse u komunikaciji s radničkim predstavnicima u vezi s procesom zaštite na radu. $O$ tome su nedavno objavljeni i radovi ${ }^{19}$ koji javnosti prezentiraju razinu te dobre prakse. Radničkim predstavnicima prezentiran je kompletni model, objašnjeni su razlozi njegova uvođenja te očekivani rezultati u njegovoj implementaciji. Radnički predstavnici imali su cijeli niz promišljanja i prijedloga, a koje su po završenom savjetovanju dostavili u pisanom obliku. Dužina ove faze uvjetovana je veličinom sustava Hrvatske pošte i zakonskom procedurom koja se mora poštovati u fazama savjetovanja sa socijalnim partnerima.

9. Faza - Dorada modela. Započela je 4. kolovoza 2013. god. sa 30 dana očekivanog trajanja. $U$ ovoj fazi proanalizirani su svi zahtjevi i promišljanja socijalnih partnera - koji su jasno prvenstveno išli u smjeru zaštite radnika što i jest sindikalna funkcija - i

${ }^{19}$ Kovač, 2017., 2018. od kojih su uvaženi i prihvaćeni oni zahtjevi koji nisu remetili ispravnost i funkcionalnost budućeg procesa ONR_min. Socijalni partneri su u ovoj fazi bili pismeno obaviješteni što je od njihovih prijedloga uvaženo, a što ne s podrobnim obrazloženjem svakog pojedinog prihvaćanja ili odbijanja.

10. Faza - Interni akti Društva. Započela je 4. rujna 2013. god. sa 60 dana očekivanog trajanja. Od ove faze započinju preklapanja s drugim fazama, a što je moguće zbog toga što se dio zadataka u samom gantogramu prenose na druge osobe i/ili organizacijske jedinice. Tako je za ažuriranje i donošenje internih akata Društva zadužen Ured za pravne poslove kojem je Služba zaštite na radu proslijedila prijedlog izmjena i dopuna internog Pravilnika o ZNR s ugrađenim detaljnim hodogramom prijavIjivanja ozljeda na radu u Hrvatskoj pošti te obvezama i odgovornostima radnika u vezi s ozljedama na radu. Pravilnik o ZNR opet je dan socijalnim partnerima, a u kojem su postupku još jednom raspravili sve formalno-pravne okolnosti budućeg sustava ONR_min i obveza radnika propisanih Pravilnikom o ZNR. Tako je novim pravilnikom u poglavlju Postupak u slučaju ozljede na radu ${ }^{20}$ kroz pet članaka vrlo precizno i detaljno opisana cijela procedura prijavljivanja ozljede na radu iz vizure radnika. S ovom procedurom po donošenju Pravilnika o ZNR u narednom razdoblju upoznati su preko svojih rukovoditelja i sindikalnih predstavnika svi radnici $\mathrm{Hr}$ vatske pošte. Ovako propisana procedura dala je formalno-pravni okvir na koji su se stručnjaci ZNR uvijek mogli pozvati u slučaju bilo kakvih poteškoća ili nejasnoća u provođenju modela ONR_min. Osim toga, interni pravilnik je po prvi puta propisao $\mathrm{i}$ odgovornosti radnika u slučaju zlorabljenja instituta ozljede na radu. Tako radnik čini povredu obveze iz radnog odnosa osobito ako ${ }^{21}$ :

- odmah po nastanku ne prijavi ozljedu na radu,

${ }^{20}$ Mance \& sur., 2013.

${ }^{21}$ Mance \& sur., 2013. 
- lažno prijavi ozljedu na radu, odnosno ako kao ozljedu na radu prijavi oštećenje za koje se naknadno utvrdi da nije bilo uzrokovano radnim procesom,

- prijavi kao ozljedu na radu oštećenje koje se nije dogodilo na uobičajenom putu s posla i na posao,

- lažno svjedoči o okolnostima nastanka ozljede na radu drugog radnika.

U ovoj fazi dorađen je i dopunjen i interni Plan i program osposobljavanja radnika, povjerenika i ovlaštenika, a po kojem su provedene i neke od sljedećih faza.

11. Faza - Edukacija rukovoditelja. Započela je 4. listopada 2013. god. sa 45 dana očekivanog trajanja. Nakon predaje prijedloga internog Pravilnika o ZNR Uredu za pravne poslove na daljnje postupanje, stručnjaci ZNR dobili su zadatak kratkom edukacijom po dorađenom Planu i programu osposobljavanja upoznati sve neposredne rukovoditelje (ovlaštenike poslodavca za ZNR) s novim modelom i obvezama njegove primjene. Odrađena su usmena predavanja po grupama područja ${ }^{22}$ gdje su svi neposredni rukovoditelji detaljno upoznati s novim modelom smanjenja ozljeda na radu u Hrvatskoj pošti, njihovim obvezama po nastanku ozljede na radu i najvažnije s obvezom preciznog upoznavanja radnika kojima rukovode s predmetnim modelom.

12. Faza - Implementacija modela. Započela je 4. studenog 2013. god. sa 45 dana očekivanog trajanja. Ova faza podrazumijevala je organizacijsko uvođenje samog modela u poslovanje Hrvatske pošte. Nastojalo se, s obzirom na veličinu sustava, upoznati što više radnika s uvođenjem novog modela $\mathrm{i}$ to preko sindikalnih glasila, internih papirnatih glasila, sustava interne društvene mreže Yammer ${ }^{23}$ i sl. Komuniciralo se ključnom informacijom kako sustav kreće s obvezom primjene od 1. siječnja 2014. god. te usmjeravanjem radnika na

\footnotetext{
${ }^{22}$ Grupe područja predstavljaju internu teritorijalnu organizacijsku strukturu Hrvatske pošte gdje se određeni broj županija fuzira u jednu Grupu područja. Hrvatska pošta podijeljena je na 6 grupa područja (GP-a), pa tako npr. GP1 podrazumijeva: Grad Zagreb, Zagrebačku županiju i Krapinsko-zagorsku županiju.

${ }^{23} \mathrm{https}$ //products.office.com/hr-hr/yammer/yammer-overview
}

proceduru propisanu internim Pravilnikom o ZNR. Na Središnjem odboru ZNR top menadžment također je upoznat s modelom te je dobivena jasna podrška top menadžmenta za provođenje predmetnog modela. Direkcija Hrvatskog zavoda za zdravstveno osiguranje je također u ovoj fazi na zajedničkom sastanku bila upoznata s predmetnim modelom i planom njegovog uvođenja. Na svim razinama Hrvatske pošte pokušalo se dati jasno i nedvosmisleno težište na važnost predmetnog modela i svrsishodnost njegove primjene na svim razinama.

13. Faza - Edukacija stručnjaka ZNR. Započela je 20. studenog 2013. god. sa 30 dana očekivanog trajanja. Svi stručnjaci ZNR detaljno su bili upoznati sa samim modelom, njihovim obvezama po nastanku svake ozljede na radu, obvezama informiranja voditelja i koordinatora službe ZNR oko svake ozljede na radu, obvezama edukacije (osposobljavanja za rad na siguran način) svakog novog radnika i po potrebi radnika koji su se višestruko ozljeđivali i svim ostalim parametrima nužnim za uspješnu provedbu predmetnog modela.

14. Faza - Testiranje/provedba modela. Započela je 1. prosinca 2013. god. sa 45 dana očekivanog trajanja. Ovo je jedina faza koja se produljila i na sljedeću kalendarsku godinu. Model je formalno organizacijski započeo 1. siječnja 2014. god., a određeno razdoblje prije formalnog početka rada i nakon njega u ovoj završnoj fazi korišten je za testiranje modela u realnom svijetu, pronalaženje određenih nedostataka modela te korigiranje i usklađivanje modela $s$ operativnim (realnim) zahtjevima.

\section{MODELIRANJE SUSTAVA ONR_min}

Sustav ONR_min modeliran je uz pomoć dijagrama toka te međunarodne norme BPMN v2.0 (engl. Business Process Model and Notation). Norma BPMN v2.0 prema Brumecu ${ }^{24}$ predstavlja skup konvencija za modeliranje poslovnog procesa, sastavljen od grafičkih elemenata i formalizira-

\footnotetext{
${ }^{24}$ Brumec \& Brumec, 2016.
} 
nih zapisa, koji ima status profesionalne norme ${ }^{25}$. Osnovni grafički oblik prikaza je nacrt poslovnog procesa BPD (engl. Business Process Diagram).

Ključna organizacijska promjena dotadašnjeg načina utvrđivanja ozljeda na radu jest u činjenici promjene uloge stručnjaka ZNR. Tako prema modelu ONR_min stručnjak ZNR iz dotadašnjeg „referenta" kojem je radnik dolazio u ured s papirologijom oko ozljede, prelazi u aktivnog i nezaobilaznog čimbenika u cjelovitom procesu. Stručnjak ZNR tako ima obvezu fizički izaći na svaku ozljedu na radu bez obzira je li se ista dogodila unutar "kruga tvrtke" ili, s obzirom na djelatnost dostave, izvan "kruga tvrtke".

Uz ovu najznačajniju organizacijsku izmjenu novi model donosi još cijeli niz novih elemenata i procedura, a koje su detaljno razrađene i teoretski definirane dijagramom toka prikazanim na slici 3. Proces će se razraditi po ključnim točkama na način da će se svaka točka opisati s osnovnim zahtjevima i uključenim sudionicima procesa:

1. Model započinje dojavom o ozljedi na radu, a koju dojavu radnik mora izvršiti odmah po nastanku ozljede. Dojavljuje se ili neposrednom rukovoditelju - koji potom odmah informira nadležnog stručnjaka ZNR ili nadležnom stručnjaku ZNR direktno. Ako radnik nije ozljedu dojavio odmah po nastanku, čini povredu obveze iz radnog odnosa i krši proceduru propisanu Pravilnikom o ZNR. Jasno ako je radnik opravdano onemogućen dojaviti ozljedu odmah (neispravnost mobilnog uređaja, zdravstveno stanje - teža ili za život opasna ozljeda), ta opravdanost mora biti dokumentirana i proces nastavlja dalje. Ovdje se željelo na samome početku izbjeći namjerno nejavljanje događaja odmah zbog pokušaja zlorabe sustava ozljeda na radu kao npr.: ozljeda se dogodila izvan radnog procesa, a radnik je pokušava podvesti pod radno-pravni status; radnik je svjesno grubo kršio pravila sigurnog rada i zbog toga se ozlijedio pa želi izbjeći utvrđivanje okolnosti na terenu; alkoholiziranost radnika; fingiranje događaja itd.
2. Po dojavi ozljede na radu, radnik mora (uvijek kada mu to zdravstveno stanje i druge okolnosti dopuštaju) ostati na mjestu događaja do dolaska nadležnog stručnjaka ZNR na mjesto nastanka ozljede. Dijagram toka tu razvodi proces na opravdano izostajanje s mjesta događaja kada radnik medicinskom ili drugom pratnjom zbog težine ozljede odlazi na hitno bolničko liječenje (ili neki drugi jasni i opravdani razlog) te neopravdano izostajanje s mjesta događaja. U drugom slučaju dodatno se dopuštaju sve nepredviđene, a opravdane okolnosti zbog kojih je radnik morao otići s mjesta događaja te u konačnici namjerni i neopravdani odlazak - bilo ih je nekoliko desetaka u promatranom razdoblju 2014.2017. - kada model predviđa neprijavljivanje ozljede na radu propisanom dokumentacijom.

Model predviđa četiri ključne mogućnosti neprijavljivanja ozljede na radu nadležnom HZZO-u i to u slučajevima kad postoje jasne i nedvosmislene okolnosti namjernog izbjegavanja i fingiranja propisane procedure. Tako iznimno važan dio samog modela čini podsustav neprijavljivanja ozljede na radu prema nadležnom HZZO-u. Ovdje se prema socijalnim partnerima, ovlaštenicima poslodavca te samim radnicima jasno komuniciralo kako cilj modela nije zakidanje ni jednog radnika u bilo kojem pravu koje može i mora konzumirati u slučaju nastanka ozljede na radu (od samog prijavljivanja, preko utvrđivanja i priznavanja ozljede, do troškova liječenja i naknade štete eventualnim sudskim postupcima), već je u ovoj fazi jedini cilj modela na vrijeme prepoznati, filtrirati i spriječiti lažno prijavljivanje ozljeda na radu te nedopušteno i nezakonito konzumiranje prava koja iz "lažne" ozljede na radu proizlaze. U poglavlju Studij slučaja prikazat će se uspješnost ili neuspješnost podsustava neprijavljivanja. Tako neprijavljivanje ozljede na radu započinje unosom podatka o neprijavljivanju u informacijsku bazu podataka te potom pisano informiranje radnika o okolnostima i razlozima neprijavljivanja. Radnik se upoznaje sa zakonskom obvezom prema kojoj Posloda- 
vac mora prijaviti ozljedu na radu u roku od osam dana, međutim kako u slučaju neprijavljivanja ozljede od strane Poslodavca - radnik može samostalno nadležnom HZZO-u prijaviti ozljedu na radu u roku od tri godine. $\mathrm{S}$ ovom informacijom je odgovorno i bez iznimke upoznat svaki radnik kojem nije prijavljena ozljeda na radu prema ovom modelu. Velika većina radnika u ovoj fazi uvidi da su detektirani u njihovom pokušaju „nekorektne konzumacije sustava" i ne odlazi na HZZO prijaviti samostalno te time slučaj i završava nepriznatom ONR, odnosno događajem koji se ne može dovesti u vezu s radno-pravnim statusom ozljede na radu. Od svih slučajeva gdje su radnici ipak odabrali opciju samostalnog prijavljivanja nadležnom HZZO-u (radi se o dvadesetak slučajeva u promatranom razdoblju 2014.-2017. god.) procedura je išla prema dijagramu toka na način da je HZZO tražio tumačenje, slučaj je potkrijepljen dokumentacijom, mišljenjem stručnjaka ZNR, opisom okolnosti događaja te preslikama procedure propisane internim pravilnikom. Niti jedan od tih slučaja u konačnici nije završio priznatom ONR od strane HZZO-a, što samo po sebi govori o kvaliteti razrađenog modela. Ovdje je važno zahvaliti Direkciji HZZO-a kao i lokalnim centrima HZZO-a po cijeloj Republici Hrvatskoj. Stručnjaci ZNR osobno su u nekoliko navrata odlazili u lokalne HZZO-e po svakom "problematičnom" događaju, u živo komunicirali probleme i nejasnoće u utvrđivanju okolnosti nastanka ozljede, komunicirali organizacijski model ONR_min u Hrvatskoj pošti te tražili pomoć i suradnju. Svi lokalni centri HZZO-a prihvatili su napore Službe zaštite na radu, uvidjeli ozbiljnost problema $s$ ozljedama na radu u Hrvatskoj pošti, te su traženu pomoć i pružili. 


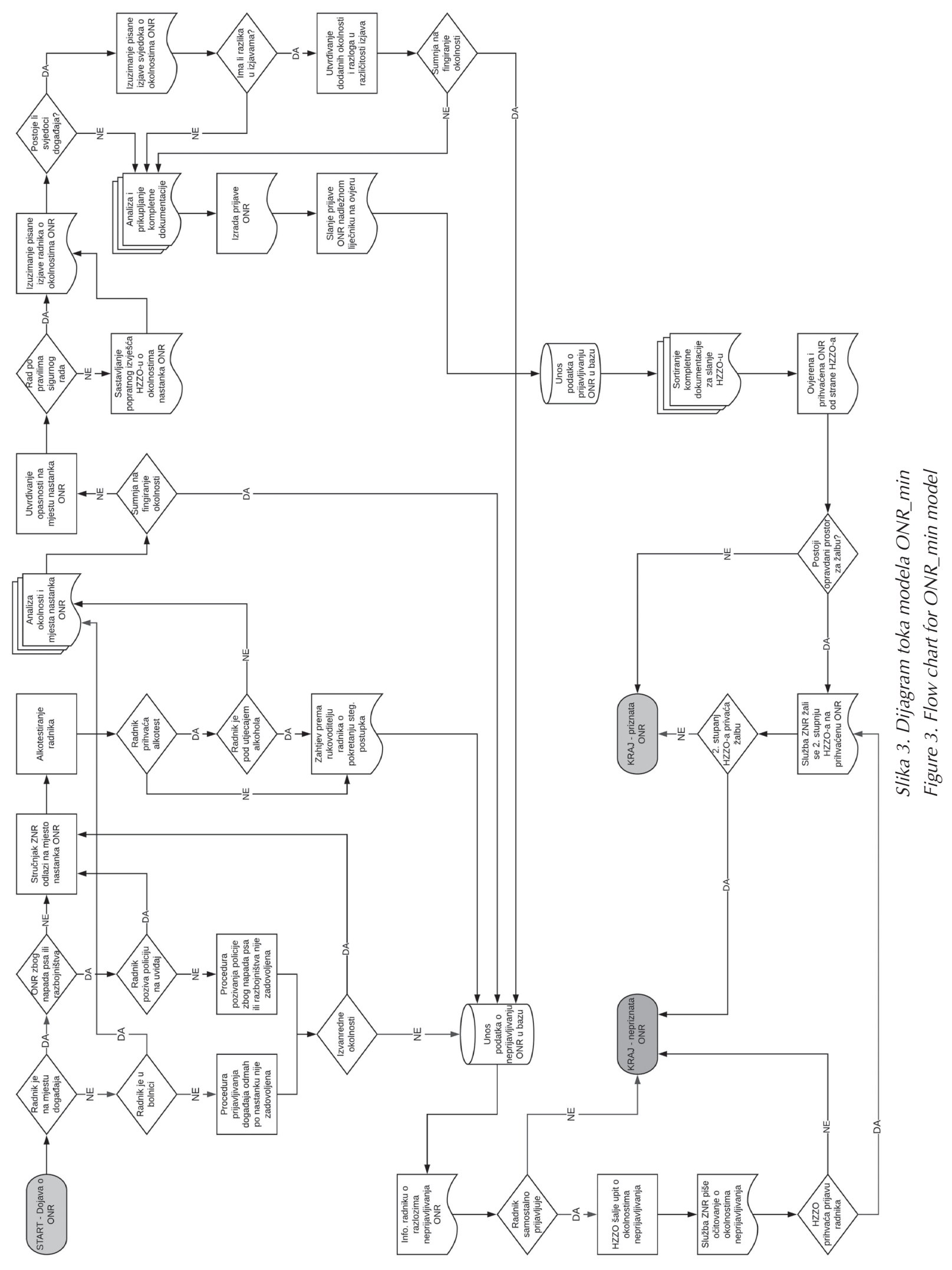


3. Sljedeći filtar predstavljaju ozljede nastale zbog napada psa ili razbojstva. Pod razbojstvom smatra se oružani prepad u poštanskom uredu ili fizički napad na poštara na dostavi. Pod napadom psa misli se na ugriz psa ili potrčavanje psa pod bicikl ili moped poštara na dostavi. Dok se kod razbojstva policija bez iznimaka pozivala kod napada pasa to nije bio slučaj. Nakon zabilježene nekolicine zloporabe instituta ozljede na radu zbog ugriza/napada psa (radnik se doslovno ogrebe na ogradu, te događaj prijavi kao ugriz psa - više u poglavlju Studij slučaja) - pozivanjem policije ulazi se u kaznenu odgovornost. Drugim riječima teško da će bilo tko riskirati kaznenu odgovornost izjavljujući neistine policiji.

4. Ako je radnik doživio ozljedu razbojstva ili napada psa, a nije pozvao policiju i za to nema opravdani razlog, proces prelazi u podsustav neprijavljivanja ozljede, opisan u točki 3 .

5. U sljedećem koraku stručnjak ZNR odlazi na mjesto događaja i prvo alkotestira radnika na mjestu događaja. Naravno, ako je radnik u bolnici ili je doživio razbojstvo, alkotest se ne provodi. U bolnici će se radnik, čim se radi o prijavljivanju ozljede u radnom procesu, podvrći vađenju krvi i između ostalog nalazu alkohola u krvi, a razbojstvo u pravilu pretpostavlja stresni događaj, a ne fizičko ozljeđivanje koji događaj HZZO priznaje kao ozljedu na radu - pa alkotest nije potreban. Stoga je u Hrvatskoj pošti od 1. siječnja 2014. god. provedeno bez iznimke alkotestiranje svakog radnika (od čistačice do direktora) koji se ozlijedio, i to na samom mjestu događaja. Koliko god ovakva procedura na prvu ostavlja dojam poslovne čvrstoće, ona je polučila jako dobre rezultate u smanjenju ozljeda na radu kao i u smanjenju alkoholiziranosti radnika na radu. Zakonodavac je ovdje vrlo jasan, pa tako čl. 67. Zakona o obveznom zdravstvenom osiguranju jasno kaže: Ozljedom na radu u smislu ovog zakona ne smatra se ozljeda do koje je došlo - između ostalog i zbog skrivljenog, nesavjesnog ili neodgovornog ponašanja na radnom mjestu (npr. obavljanje poslova pod utjecajem alkohola). ${ }^{26}$ Ako se, dakle, radniku utvrdi da je pod utjecajem alkohola, proces odmah prelazi u podsustav neprijavljivanja ozljede na radu te se prema radniku, a u skladu s internim Pravilnikom o zaštiti na radu, pokreće postupak utvrđivanja odgovornosti. Važno je napomenuti kako HZZO bez iznimke nije priznavao ozljedom na radu svaku onu ozljedu koja se dogodila pod utjecajem alkohola (u slučajevima kad je alkoholizirani radnik ipak sam prijavio HZZO-u).

6. Proces dalje prelazi na element analize okolnosti i mjesta nastanka ozljede na radu. Dakle, radnik, eventualni očevidac i stručnjak ZNR zajednički prolaze samo mjesto ozljede, analizirajući što i kako se dogodilo, koje su opasnosti, štetnosti i napori te kako se takav ili sličan slučaj može prevenirati u budućnosti. Ovo je iznimno koristan element sustava ONR_min jer u najvećem dijelu pruža vrlo korisne informacije o tome što, gdje i zašto se dogodilo - čime se puni baza znanja o sličnim događajima u budućnosti koji se potom na razini Službe zaštite na radu preveniraju. $U$ manjem dijelu ovaj element također otvara (na žalost) pokušaj fingiranja radnika, a u kojem slučaju proces predviđa isto tako prelazak na podsustav neprijavljivanja. $U$ ovom koraku detekcija eventualnog fingiranja nije prepuštena dobroj volji stručnjaka ZNR nego je unaprijed definirana zadanim parametrima i vrlo konkretnim obrazloženjima. U poglavlju studija slučaja prikazat će se slučaj u kojem se u ovom koraku detektiralo fingiranje radnika. Ono što je ključno jest, kako je već navedeno, povećano znanje na moguće izvore opasnosti koje ovaj korak omogućuje. Npr.: u jednom velikom poštanskom centru aparat za kavu bio je postavljen izvan prostora natkrivenog skladišta, kako radnici koji dolaze po kavu ne bi ometali radni proces utovara i istovara robe. Međutim, radnici su iz ureda morali prolaziti cijeli kolni prostor da bi došli do tog aparata za kavu. U konkretnom slučaju radnica se - noseći u

\footnotetext{
${ }^{26} \mathrm{https} / / / w w w . z a k o n . h r / z / 192 / Z a k o n-o-o b v e z n o m-z d r a v s t v e n o m-$ osiguranju
} 
rukama dvije kave prolaskom preko prostora skladišta - spotakla preko propisno spuštenih vilica viličara te $u$ padu na te vilice zadobila višestruke prijelome podlaktice. Isključivo je ovaj korak modela ONR_min omogućio precizno utvrđivanje okolnosti i detektirao problem u pogrešno lociranom aparatu za kavu. Zaista je suludo da masa uredskih radnika koji nisu educirani za siguran rad i sigurno kretanje po skladištu mora svakodnevno prolaziti kroz cijeli prostor skladišta da bi kupili kavu. Moramo podsjetiti kako se govori o poslovnom sustavu s preko 1.000 lokacija i oko 10.000 radnika, te da je Službi zaštite na radu koja broji 26 radnika nemoguće na dnevnoj razini locirati svaki mogući izvor opasnosti. Stoga je ovaj korak od iznimnog značaja za unapređenje sigurnosti na radu, a iz kojeg su proizašla mnoga pravila i upute postupanja u sustavu Hrvatske pošte.

7. Jedan od zadnjih koraka prije pripreme obrasca ozljede na radu i predaje dokumentacije nadležnom liječniku te potom HZZO-u jest izuzimanje izjava radnika i eventualnog očevica. Obje izjave izuzimaju se odmah ili što prije, dok je događaj svjež, ako je ikako moguće već na samom mjestu nastanka ozljede. Pisane izjave radnika i očevica opisuju cijeli događaj iz vizure radnika i mogu prilično koristiti u rasvjetljavanju cijelog događaja. Međutim, one mogu također biti i zadnji filtar utvrđivanja istinitosti cijelog događaja. Tako se nije jednom dogodilo da se izjava radnika dijametralno razlikuje od njegove prezentacije događaja u živo ili da se izjave radnika i očevica dijametralno razlikuju. $U$ slučaju da izjave jasno ukazuju na opravdanost sumnje u fingiranje događaja prelazi se u četvrtu i posljednju opciju neprijavljivanja ozljede na radu.
8. Na kraju modela prikuplja se sva potrebna dokumentacija, izrađuje se prijava ozljede na radu, ista se ovjerava kod nadležnog liječnika obiteljske medicine te se prosljeđuje nadležnom HZZO-u na pregled i ovjeru. Model i ovdje predviđa mogućnost žalbe drugom stupnju, a koja je u nekoliko navrata i konzumirana. Radilo se o suspektnim slučajevima, međutim zbog bogatog iskustva pojedinaca u "konzumiranju" instituta ozljede na radu bili su zadovoljeni svi formalni uvjeti, a zbog čega se prijava ozljede morala provesti. Međutim, tada se iskoristila mogućnost žalbe drugom stupnju, a gdje se pokušalo razjasniti zbog čega postoji sumnja na istinitost samog događaja.

9. Priznavanjem ili nepriznavanjem ozljede na radu od strane nadležnog HZZO-a ili drugog stupnja HZZO-a sam proces ONRmin i završava.

Poslovni proces ONR-min pojednostavljeno se modelirao i primjenom međunarodne norme BPMN v2.0, a što se može vidjeti na slici 4 .

Vidi se kako se proces utvrđivanja ozljeda na radu sastoji od tri potprocesa, i to: radnik, stručnjak ZNR i HZZO. Tako se potproces radnik sastoji od tri ključne "skretnice" - odnosno tri ključne aktivnosti radnika odmah po nastanku ozljede na radu: odmah dojaviti događaj nadležnim osobama te pozivanje policije prilikom ugriza psa i/ ili razbojstva. Potproces stručnjak ZNR je najsloženiji što je i logika cijelog procesa s obzirom da stručnjak ZNR ima najviše aktivnosti i obveza oko samog prijavljivanja ozljede na radu te je i najzaslužniji za ispravnost ili neispravnost procesa. Ovdje svakako treba spomenuti bazu ZNR, odnosno informacijski sustav praćenja zaštite na radu, a koji je implementiran u poslovanje $\mathrm{Hr}$ vatske pošte dvije godine prije uvođenja modela ONR_min. 


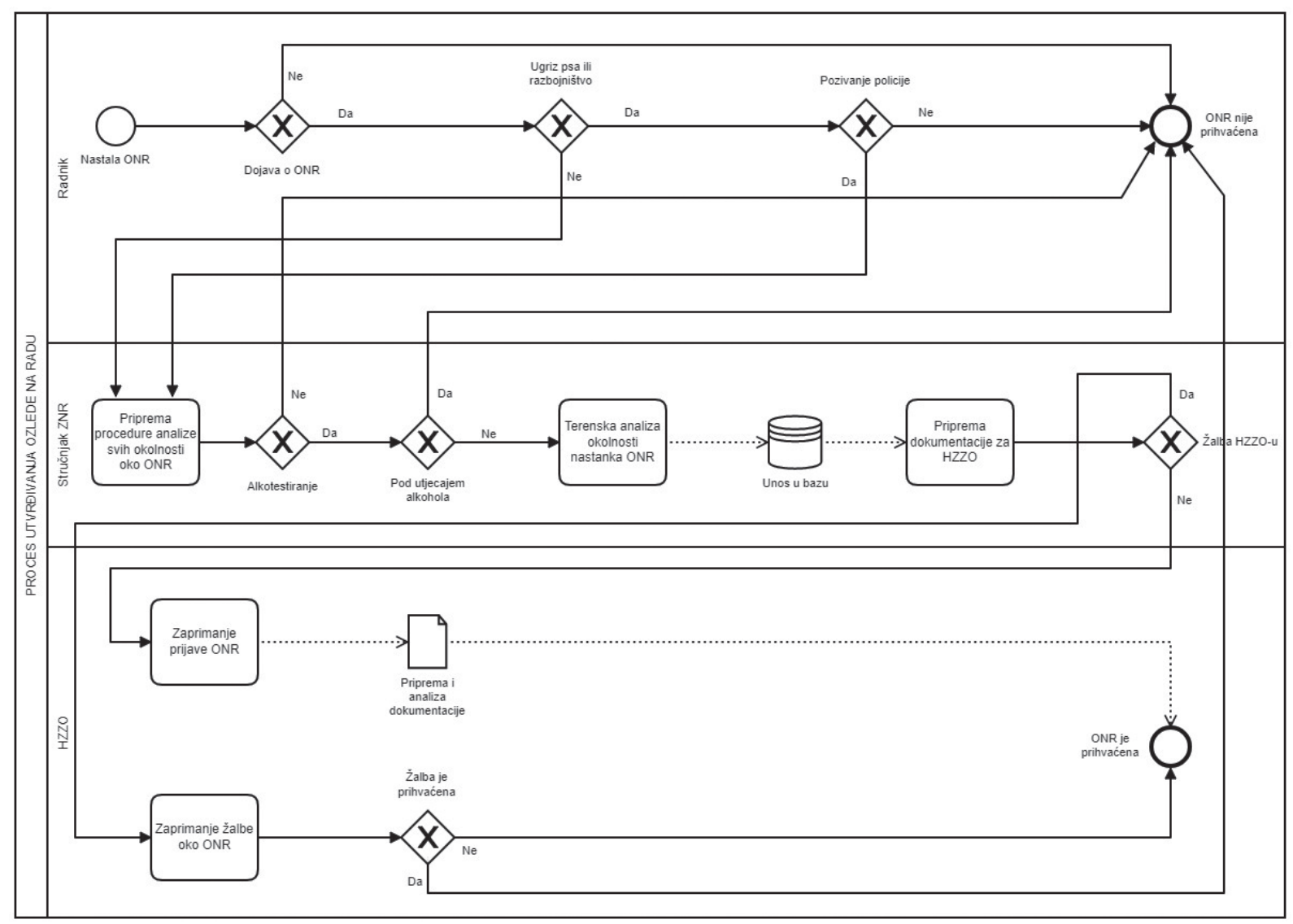

Slika 4. Dijagram procesa ONR_min

Figure 4. Process chart for ONR_min

Radi se o bazi podataka koja je prvotno bila izrađena na MS Access platformi ${ }^{27}$ da bi kasnije bila dorađena komercijalno dostupnom aplikacijom WEB ZNR ${ }^{28}$ koja je dodatno bila prilagođena potrebama Hrvatske pošte. Predmetni sustav informatizirao je sve aktivnosti zaštite na radu i zaštite od požara koje se provode kroz određene obrasce, evidencije, izvješća i sl. poput: prijavljivanja ozljeda na radu, izrade godišnjih izvješća (dok je to bila obveza) o ozljedama na radu, generiranje izvješća o ozljedama na radu za potrebe Poslodavca, redovitih pregleda vatrogasnih aparata, evidencije o lokacijama vatrogasnih aparata, podaci o ispitivanju strojeva i uređaja s povećanim opasnostima, radnog okoliša, napona indirektnog dodira, otpora izolacije i dr., podaci o osposobljavanjima iz ZNR i ZOP za svakog pojedinog radnika i cijeli niz drugih.

\footnotetext{
${ }^{27}$ https://products.office.com/hr-hr/access

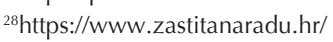

Potproces HZZO generalno sadrži dva segmenta: zaprimanje prijave ONR ili zaprimanje žalbe oko događaja koji se pokušava podvesti pod ozljedu na radu.

\section{STUDIJ SLUČAJA}

Prema Biličiću ${ }^{29}$ proučavanje slučaja je posebna metoda kojom se podaci sređuju $\mathrm{i}$ iskazuju $\mathrm{s}$ ciljem da se očuva jedinstveni karakter predmeta. To je metoda kojom se predmet, a to je pojedinac ili neka društvena jedinica, nastoji zahvatiti u cjelini. Posebno težište Biličić stavlja na znanstveno istraživanje metodom slučaja u privrednim organizacijama: „Možemo zaključiti da je u izučavanju privrednih organizacija metoda slučaja vrlo korisna i to kod formuliranja hipoteza koje

${ }^{29}$ Biličić, 2005. 
se provjeravaju daljnjim istraživanjima te kod stvaranja znanja primjenjivih u praksi. Uz to, ima nekih problema koji se mogu izučiti samo promatranjem slučajeva, kao npr. proces stvaranja odluka." ${ }^{\prime 30}$

Upravo ovdje stavlja se težište na istraživanje metodom studija slučaja, a kako bismo vidjeli na koji način su u modelu ONR_min provođeni elementi procesa, te na koji način je njihovo provođenje utjecalo na donošenje odluke oko toga da li neki događaj smatrati ili ne smatrati ozljedom na radu.

\section{Slučaj 1. - namjerna opstrukcija stručnjaka ZNR}

Težište uspješnosti provedbe modela ONR_ min jest na ozbiljnosti, angažiranosti i stručnosti stručnjaka ZNR koji predmetni model provode u praksi. Svih 26 stručnjaka ZNR Hrvatske pošte su osobe više ili visoke stručne spreme tehničkog smjera, s položenim stručnim ispitom te radnim iskustvom od 3 ili više godina u ZNR. Dakle, njihova samostalnost i stručnost nije upitna te je $s$ obzirom na takve reference bilo za očekivati da će model ONR_min u tom dijelu funkcionirati bez problema. Međutim, iskustva u praksi upućuju na tipičan menadžerski problem promjena unutar poslovnog sustava. Tako prema prof. Dujaniću ${ }^{31}$ pobornike promjena dočekuju sumnjivošću, ljutnjom, otporom pa i sabotažom. Problem se odnosi na blokiranje aktivnosti od strane ljudi zbog njihovih raznih interesa. $U$ takvoj situaciji podređuju se poslovni ciljevi osobnim ciljevima svojih suparnika, zbog toga se ne može postići cilj poduzeća. Jedina prihvatljiva mogućnost u toj situaciji je: izazvati sredinu i ne bojati se da ćete među kolegama steći neprijatelje kako bi ostvarili utvrđene ciljeve kompanije.

Može se reći kako je rukovodstvo Službe zaštite na radu iskusilo slična iskustva od strane pojedinih stručnjaka ZNR prilikom uvođenja modela ONR_min koji su se očitovali dijelom u ljutnji, a dijelom u pružanju otpora. Opetovanim inzistiranjem na ispravnom provođenju modela, edukacijom stručnjaka ZNR u nekoliko navrata, te redovitom kontrolom procesa ovi otpori su prevladani. Ključni korak bio je u zahtjevu slanja svakog po-

${ }^{30}$ Biličić, 2005.

${ }^{31}$ Dujanić, 2004. stupka s popratnom dokumentacijom i kratkim obrazloženjem što je učinjeno i što je stručnjak ZNR odlučio - rukovodstvu službe ZNR. Tu bi se ispravljali određeni propusti, tumačile nejasnoće te se inzistiralo na ispravnom provođenju svakog pojedinog procesa njegovom kraju. S predmetom, odlukom o postupanju te time i doradom modela ONR_min u konačnici su upoznati svi stručnjaci ZNR. Ovakvim pristupom, komunikacijom i poslovičnim inzistiranjem na ispravnosti riješio se problem otpora promjenama unutar organizacije ZNR. Međutim, nikakav menadžerski alat ne može pomoći u onome što prof. Dujanić naziva sabotažom. Tako je jedna namjerna sabotaža od strane stručnjaka ZNR završila opomenom pred otkaz za tog stručnjaka ZNR te svakako "stjecanjem neprijatelja“ među kolegama.

Stručnjak ZNR iz Zagreba 2015. god. dobiva pisano upozorenje na obveze iz radnog odnosa (opomena pred otkaz) od strane Poslodavca jer je u predmetu ozljede na radu radnika iz Zagreba postupio neovlašteno i protivno poslovnoj politici Poslodavca. Nakon utvrđivanja okolnosti oko ozljede na radu radnika i predaje potrebne dokumentacije nadležnom HZZO-u, dolazi rješenje o nepriznavanju ozljede na radu. Nadležni HZZO ispravno procjenjuje kako se opisani događaj ne može podvesti pod aktivnosti koje imaju vezu s obavljanjem radnih poslova i zadataka i takvo rješenje dostavlja radniku i Poslodavcu. Tada stručnjak ZNR samostalno i u dogovoru s radnikom pokreće postupak žalbe na predmetno rješenje o nepriznavanju ozljede na radu te za vrijeme radnog vremena i resursima Poslodavca kreće u neovlašteno zastupanje radnika. Nadležni HZZO odgovara zahtjevom za punomoć u zastupanju radnika i tada nadležni stručnjak ZNR slučaj rasteže do krajnjih granica nedopuštenog na način da od rukovodstva Službe zaštite na radu traži po dopisu HZZO-a - ishodovanje punomoći od strane Uprave Društva za zastupanje radnika. Tu je očita i konfuznost stručnjaka ZNR jer se po tom njegovom zahtjevu pokreće proces utvrđivanja odgovornosti. U konačnici se utvrđuje namjerno i nesavjesno postupanje stručnjaka ZNR po kojem i dobiva opomenu pred otkaz.

Nakon ove namjerne sabotaže kao najozbiljnijeg slučaja otpora promjenama stručnjak ZNR shvaća da će naredne namjerne opstrukcije izazvati njegov otkaz ugovora o radu te staje s istima, 
obavljajući u sljedećem razdoblju posao utvrđivanja ozljeda na radu po modelu ONR_min savjesno i odgovorno, ali uvijek s „neprijateljskim stavom" prema rukovodstvu Službe zaštite na radu.

\section{Slučaj 2. - fingiranje okolnosti od strane radnika}

Radnik iz Splita 2017. god. prijavljuje slučaj koji podvodi pod ozljedu na radu. Navodno radnik pada na jednom stubištu stambene zgrade dostavljajući poštu, odlazi u KBC Split na hitni prijem, prijavljuje pad na radu te mu se utvrđuje dijagnoza kontuzija prsnog koša. Potom radnik prijavljuje događaj nadležnom stručnjaku ZNR koji odlazi na mjesto događaja te utvrđuje kako je predmetno stubište osvijetljeno, čisto, uredno, prohodno, suho i ima rukohvat. Opisivanjem okolnosti nastanka ozljede radnik ne uspijeva precizno objasniti kako i gdje je pao te navodno udario prsima u stubu pa shodno tome nadležni stručnjak ZNR ispravno izražava sumnju u istinitost događaja. Daljnjom analizom okolnosti utvrđuje se kako radnik ima već 6 ozljeda na radu kao apsolutni rekorder, a koje su sve sličnog karaktera pada, uganuća itd. Nadalje, radnik, po izjavi neposrednog rukovoditelja, taj isti dan odmah po preuzimanju smjene biva usmeno upozoren od strane neposrednog rukovoditelja na opstruiranje poslovnog procesa i namjerno usporavanje pripremnih radnji za dostavu. Radnik pritom izražava svoje negodovanje novim rasporedom rajona dostave, kojem pripada i stambena zgrada u kojoj navodno par sati kasnije doživljava ozljedu na radu. Zbog svih navedenih okolnosti donosi se odluka o neprijavljivanju ozljede na radu, o istoj se obavještava radnik s tumačenjem kako događaj može prijaviti samostalno nadležnom HZZO-u. Radnik koristi to pravo, HZZO potom traži očitovanje nadležnog stručnjaka ZNR, rukovoditelja i samog radnika. U svojem očitovanju radnik navodi kako je u toj i toj zgradi „pao na skaline, a da se ozljeda mogla izbjeći da mu nisu pretrpali torbu poštom i paketima zbog kojih je imao slabu preglednost i nije se mogao dočekati na ruke prilikom pada." Radnik zaključuje kako je „cijeli događaj uredan i valjan te očekuje da mu se prizna ozljeda na radu“. Ne samo da je netočna konstatacija pretrpane torbe jer je masa poštanske torbe odavno ograničena na $15 \mathrm{~kg}$, a radnici imaju mogućnost odabira i torbi s kotačićima za prijenos pošiljaka, nego se postavlja i pitanje na temelju čega radnik konstatira da je cijeli događaj uredan i mora biti ozljeda na radu? Očito je veliko iskustvo radnika u institutu ozljede na radu te nekorektnom konzumiranju istog (pokušaj simuliranja 7. ozljede), a što je ispravno zaključio i nadležni HZZO odbivši rješenjem radnikovu prijavu ozljede na radu tumačenjem kako se ne može sa sigurnošću utvrditi mjesto, način i vrijeme nastanka ozljede na radu. Zaključno direktor radnika i nadležni stručnjak ZNR po pravomoćnosti rješenja HZZO-a obavljaju razgovor s radnikom. Upozoravaju ga kako su za fingiranje ozljeda na radu propisane mogućnosti povrede radne obveze te da je vrlo upitna njegova sposobnost obavljanja poslova dostave ako svako toliko ima razne padove, uganuća i sl., a zbog kojih je posljednjih godina 6 puta prijavljivao ozljede na radu. Naravno, nakon ovoga radnik do danas nije više imao niti jednu ozljedu na radu.

\section{Slučaj 3. - nesavjesno i nemarno obavljanje poslova}

Radnik u Rijeci 2015. god. obavlja poslove poštara opće dostave kao pješak. Bez znanja neposrednog rukovoditelja za obavljanje navedenih poslova jedne prilike odlučuje voziti svoj privatni moped te doživljava prometnu nezgodu. Radnik prijavljuje događaj, no u svojoj izjavi obrazlaže i potpisuje kako neće prijavljivati ozljedu na radu jer je svjestan da je postupio nesavjesno u obavljanju poslova vozeći privatni moped, i dodatno zato što je on svojim ponašanjem u prometu izazvao prometnu nezgodu. Međutim, uskoro nadležni HZZO traži očitovanje o podnesenoj prijavi o ozljedi na radu koju je radnik bez obzira na potpisanu izjavu, samostalno prijavio. Dakle, ne samo da je radnik raspoređen na radno mjesto poštonoša pješak te kao takav ne duži osobnu zaštitnu opremu niti je osposobljen za rad na siguran način za poštonošu mopedista, već se neovlašteno i bez znanja rukovoditelja koristi privatnim mopedom za dostavu. Doživljava vlastitom krivnjom prometnu nezgodu, potpisuje izjavu da je svjestan svih svojih propusta i bez obzira na sve navedeno samostalno prijavljuje ozljedu nadležnom HZZO-u. Po očitovanju Poslodavca nadležnom HZZO-u isti donosi rješenje o nepriznavanju ozljede na radu iz razloga nesavjesnog i nemarnog obavljanja poslova, a u 
skladu sa čl. 67. Zakona o obveznom zdravstvenom osiguranju. Zaključno radnik dobiva i pisano upozorenje na obveze iz radnog odnosa jer je neovlašteno i neodgovorno obavljao poslove na koje je raspoređen, a protivno internom Pravilniku o radu.

\section{Slučaj 4. - ozljeda koja je nastala zbog osobnog odnosa koji se ne može dovesti u kontekst radne aktivnosti}

Godine 2016. radnik obavlja poslove dostave pošiljaka na terenu u okolici Splita, pri čemu ga je vlasnik stana pozvao da uđe u stan te ga nakon toga udario šakom u glavu. Radnik je uspio pobjeći i o događaju obavijestiti voditelja područja, stručnjaka za zaštitu na radu te pozvati policiju. Dakle, radnik postupa u skladu sa svim pravilima modela ONR_min. Policija obavlja očevid na mjestu događaja te o tome sastavlja svoje izvješće. Radniku se pruža liječnička pomoć u KBC Split. S obzirom na sve poznate i dostupne okolnosti stručnjak za zaštitu na radu nakon obavljenog razgovora s ozlijeđenim radnikom, voditeljem područja te nakon uvida u medicinsku dokumentaciju ispunjava obrazac prijave ozljede na radu i istu upućuje na odlučivanje nadležnoj službi HZZO-a.

HZZO početkom 2017. god. donosi rješenje kojim se radniku događaj od kraja 2016 god. ne priznaje ozljedom na radu. Prilikom donošenja odluke o pravu radnika, HZZO traži službenu zabilješku MUP-a Republike Hrvatske u kojoj se navodi: vlasnik stana poziva poštara u stan gdje se nalazila i strankina maloljetna kćer od dvije godine koja je prepoznala poštara i rekla ocu kako poštar dira mamu za "cike" (dojke), nakon čega mu je vlasnik stana oduzeo mobitel te ga otvorenim dlanom počeo udarati po glavi. Radnik je uspio ugrabiti mobitel i pobjeći iz stana nakon čega je događaj prijavio policiji. Hrvatski zavod za zdravstveno osiguranje u rješenju kojem se radniku ne priznaje ozljeda na radu navodi da je u provedenom postupku utvrđeno da je do nastanka ozljede došlo zbog namjernog nanošenja ozljede od strane druge osobe izazvanog osobnim odnosom s osiguranom osobom koji se ne može dovesti u kontekst radno-pravne aktivnosti, te da iz tog razloga nisu ispunjeni uvjeti za priznavanje događaja ozljedom na radu.
Uspješnost modela ONR_min ovdje se očituje u već spomenutoj činjenici da su stručnjaci ZNR po uvođenju modela u nekoliko navrata obavljali razgovore i savjetovanja s nadležnim HZZO-om, a po kojim sastancima HZZO počinje stavljati težište na analizu prijava ozljeda na radu koje dolaze iz sustava Hrvatske pošte.

\section{Slučaj 5. - alkoholiziranost radnika prilikom ozljeđivanja}

Radnik u Zagrebu 2017. god. ozlijedio se pri padu na stubištu stambene zgrade u Centru prilikom dostave pošiljaka. Ispravno poziva nadležnog stručnjaka ZNR na mjesto događaja, a gdje ga je i pričekao da bi zajednički utvrdili sve okolnosti. Stručnjak ZNR prvo pristupa alkotestiranju radnika te propisanom procedurom utvrđuje 1,48 promila alkohola u krvi radnika. Nadležni stručnjak ZNR poziva neposrednog rukovoditelja radnika, radnik se udaljuje s mjesta rada, zaustavlja se postupak prijave ozljede na radu te se radnika o svemu informira. Radnik svjestan svojeg nesavjesnog ponašanja (alkoholiziranost) prihvaća činjenicu kako se tu ne može raditi o ozljedi na radu u smislu čl. 67. Zakona o obveznom zdravstvenom osiguranju. Radnik ne konzumira svoje pravo samostalnog prijavljivanja ozljede na radu. Neposredni rukovoditelj radnika po službenoj dužnosti pokreće postupak utvrđivanja odgovornosti radnika te radnik dobiva pisano upozorenje na obveze iz radnog odnosa.

\section{Slučaj 6. - fingiranje ozljede nastale zbog ugriza psa}

Prema čl. 60. Kolektivnog ugovora ${ }^{32}$ Hrvatska pošta svakom ozlijeđenom radniku isplaćuje naknadu od:

- 2.000,00 kn u slučaju psećeg ugriza prilikom obavljanja poslova te

- 15.000,00 kn u slučaju pretrpljenog straha, boli, umanjenja životnih aktivnosti i naruženosti nastale zbog neposredne izloženosti razbojstvu na radnom mjestu.

\footnotetext{
${ }^{32}$ http://www.sindikat-hsp.hr/dokumenti/Kolektivni\%20 ugovor\%202018-2020\%20cistopis.pdf
} 
Dok je iz vizure Poslodavca ova odredba Kolektivnog ugovora vrlo napredna i suvremena, te njom Poslodavac prepoznaje specifične opasnosti pojedinih radnih mjesta i na financijski ih način pokušava amortizirati, iz vizure struke zaštite na radu, a ocjenjujući uspješnost same odredbe u praksi, ona jest iznimno dvojbena i upitnog učinka. Ne umanjujući ozbiljnost ugriza pasa i razbojstava u Hrvatskoj pošti koje su bile i jesu vrlo specifične i izražene ozljede, s dugotrajnim psihičkim posljedicama, smatra se kako financijskom naknadom (ovdje se misli isključivo na ozljede zbog napada psa, ne i na ozljede zbog razbojstva) nisu polučili željeni rezultat nego su štoviše isprovocirani pojedini pokušaji zloporabe sustava. Prepoznavši konkretne probleme na terenu Služba zaštite na radu je još 2012. god. predložila ukidanje ovih naknada te rješavanje stvarnih posljedica ovih ozljeda na radu cijelom paletom stručnih, organizacijskih i poslovnih aktivnosti, međutim do danas se ova odredba nije značajnije promijenila u kolektivnim pregovorima. Stoga se uvođenjem modela ONR_min specificiralo i inzistiralo na obveznom pozivanju policije i zbog napada psa i zbog razbojstva. Dok se kod razbojstva policija bez iznimaka pozivala, kod napada pasa to nije bio slučaj.

Tako radnik iz Istre 2015. god. prijavljuje nadležnom stručnjaku ZNR ozljedu nastalu zbog napada psa, no dan nakon samog događaja, donoseći medicinsku dokumentaciju o ozljedi šake (ogrebotini). Na upit stručnjaka ZNR zašto nije prijavio događaj odmah po nastanku i pozvao policiju na uviđaj radnik reagira ljutnjom, bez konkretnog obrazloženja i zahtjevom da mu se prijavi ozljeda na radu. Radnik nema očevidca događaja, radnik navodi kako se radi o psu lutalici te da je zato mislio kako nema potrebe pozivati policiju. Od rukovoditelja radnika stručnjak ZNR dobiva informaciju da ovaj nema nikakvih saznanja o događaju. Analizom podataka u bazi ZNR stručnjak ZNR utvrđuje iznimno zanimljiv podatak. Dotični radnik zadnjih 7 godina, u redovitim razmacima jednom godišnje prijavljuje ozljedu zbog napada psa, uvijek prema istom ili sličnom hodogramu - pas lutalica, bez svjedoka. Ozljeda mu se bez analize priznaje te radnik povlači 2.000,00 kn naknade iz Kolektivnog ugovora. Stručnjak ZNR u dogovoru s rukovodstvom Službe zaštite na radu ne ispunjava prijavu ozljede na radu zbog očigledne sumnje $u$ istinitost događaja te o tome obavještava radnika i njegovog rukovoditelja. Na lokalnom Odboru ZNR raspravlja se o ovom događaju te direktor radnika nakon tog sastanka razgovara s radnikom upozoravajući ga na utvrđene okolnosti. Radnik ne prijavljuje samostalno događaj nadležnom HZZO-u te se postupak obustavlja. Naravno, od tog događaja do danas dotični radnik više nije ima niti jednu ozljedu na radu zbog napada psa.

Iz prikazanih studija slučaja jasno je kako se institut ozljede na radu ponekad zlorabio, kako je umješnost pojedinih radnika u dijelu fingiranja okolnosti bila na visokoj razini, kako se ozljeda na radu koristila kao osveta rukovoditelju za promjenu radnog mjesta ili radnih obveza, kako su se pojedine financijske naknade zlorabile te u konačnici kako je i manji dio stručnih osoba - stručnjaka ZNR - pružao otpore uvođenju modela ONR_min i/ili pokušao opstruirati pojedine procese. Ustrajnost većine stručnjaka ZNR koje svakako i ovom prigodom valja pohvaliti za njihovu radišnost $i$ predanost u ciljevima koji su im po predmetnom modelu postavljeni, ipak je dovela do respektabilnih rezultata, koji su se popravljali iz godine u godinu, a kako će niže i biti prikazano. Ustrajnost na provođenju modela ONR_min, opetovano učenje iz pojedinih slučajeva koji su se dijelili cijeloj Službi zaštite na radu, trajne edukacije radnika $\mathrm{i}$ rukovoditelja, intenzivirana suradnja sa svim ispostavama HZZO-a te anuliranje one manje „nepodobne" skupine radnika koja uvijek pokušava opstruirati na svim razinama, u narednom razdoblju postigli su se prikazani rezultati (slika 5). 


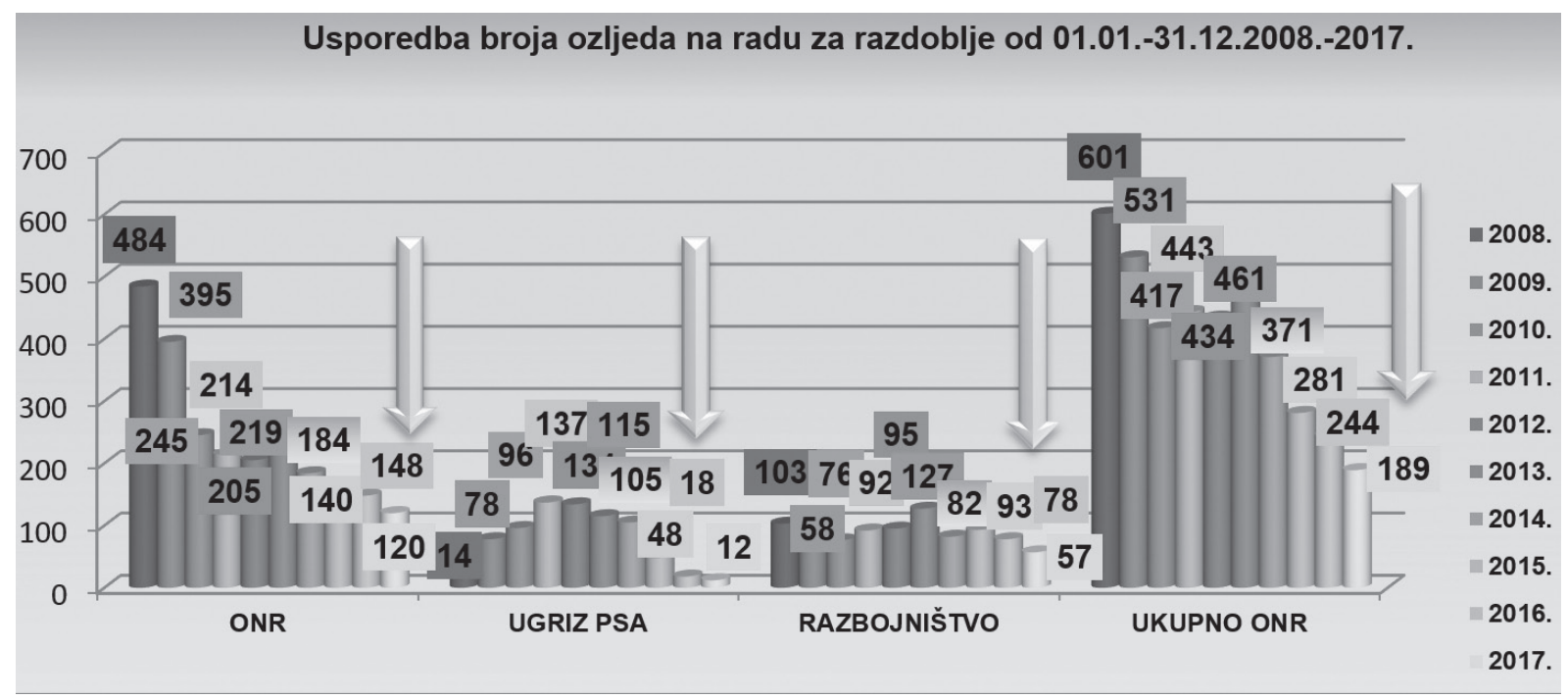

Slika 5. Ukupan broj ONR 2008.-2017.- apsolutni broj

Figure 5. Total number of ONR 2008-2017 - absolute number

Pod ONR misli se na sve ozljede nastale u prometu, na dostavi, u sustavu Hrvatske pošte te na putu s posla i na posao. Pod ugrizima psa misli se na ugrize i napade pasa, a pod razbojstvom na ozljede nastale pljačkom u poštanskom uredu ili razbojstvom na poštara prilikom dostave. Upravo su ozljede nastale zbog razbojstva doživjele najmanje oscilacije jer su ovisne o prosječnom broju razbojstava na sustave u kojima se posluje gotovim novcem i vrijednostima poput banaka, pošta, benzinskih crpki, mjenjačnica, kladionica i sl. Ovdje je u kontekstu modela ONR_min bilo ključno povesti računa da su radnici pozvali policiju (što je uvijek i bez iznimke bio slučaj) te da se zbog "akutnog stresa" u kontekstu ozljede na radu prijavljuju samo oni radnici koji su bili sudionici predmetnog razbojstva. Napadi pasa kao i ukupne ozljede na radu prikazuju rapidan pad od početka 2014. god. i implementiranog modela ONR_min pa do kraja 2017. god. Analizirajući ukupan broj ozljeda na radu vide se sljedeći rezultati:

- 2008. god. završava kao apsolutni maksimum sa 601 ONR

- 2012. god. kao razdoblje intenzivnih upozorenja o stanju ONR od strane HZZO-a završava sa 434 ONR

- pad ukupnog broja ONR od početka 2008. do kraja 2012. iznosi 138,5 \% odnosno u ukupnom broju to iznosi točno 579 ONR manje na kraju 2012. god. u odnosu na to da su ONR ostale na razini 2008. god.

- 2013. god. završava s ukupno 461 ONR i predstavlja referentnu godinu modeliranja sustava ONR_min te u konačnici njegovu implementaciju

- 2014.-2017. god. predstavljaju razdoblje intenzivne uporabe modela ONR_min u praksi te 2017. god. završava s ukupno 189 ONR

- $\quad$ pad ukupnog broja ONR od početka 2013. do kraja 2017. iznosi 244\% odnosno u ukupnom broju to iznosi točno 759 ONR manje na kraju 2017. god. u odnosu na to da su ONR ostale na razini 2013. god.

- za cijelo analizirano razdoblje od početka 2008. god. do kraja 2017. god. govori se o smanjenju od $318 \%$, odnosno u ukupnom broju to iznosi točno 2038 ONR manje u odnosu na to da su ONR ostale na razini 2008. god.

Analiza ukupnog broja ONR ciljano je podijeIjena na dva razdoblja: četiri godine prije i četiri godine nakon uvođenja modela ONR_min. Tako su u prvom razdoblju za smanjenje ozljeda na radu u Hrvatskoj pošti korištene sve one poznate i u struci zaštite na radu priznate metode. Primjenom organizacijskih, tehničkih, obrazovnih i dru- 
gih aktivnosti struke zaštite na radu radilo se na prevenciji i smanjenju ozljeda na radu. Interno je timski izrađena kvalitetna Procjena opasnosti (danas Procjena rizika), u njezin plan mjera implementirane su sve uočene opasnosti, štetnosti i napori radnih mjesta, na svakom od sedam odbora zaštite na radu inzistiralo se na uklanjanju tehničkih neispravnosti i nedostataka (u odbore je uključena org. jed. održavanja), obavljani su redoviti interni nadzori od strane stručnjaka ZNR kao apsolutni novitet u Hrvatskoj pošti, po internim nadzorima zatraženo je također uklanjanje uočenih nedostataka, potpuno je promijenjen is Procjenom rizika usklađen Plan osposobljavanja za rad na siguran način, obrazovna literatura i testovi, a implementacijom baze ZNR informatizirani su svi administrativni poslovi ZNR i ZOP itd. Sve ove aktivnosti pokazale su se stručno utemeljene, ispravne i u kontekstu prevencije ozljeda na radu svrsishodne te su i rezultirale značajnim smanjenjem ukupnog broja ozljeda na radu.

Međutim, HZZO nas osvještava i upozorava 2012. god. kako je Hrvatska pošta u prilično lošoj poziciji u vezi s ukupnim brojem ozljeda na radu te postaje jasno kako se "konvencionalnim" odnosno priznatim i poznatim metodama neće moći puno više učiniti te se pristupa modeliranju ovdje opisanog sustava ONR_min. Tako je 2013. god. i najbolji pokazatelj dosega konven- cionalnih metoda ZNR, gdje se unatoč njihovoj kontinuiranoj primjeni ozljede na radu čak i povećavaju u odnosu na 2012. god.

Iz ove analize smanjenja ukupnog broja ONR očito je kako je model ONR_min $31 \%$ uspješniji u smanjenju ozljeda na radu od primjene konvencionalnih metoda zaštite na radu. $U$ analizi stope ONR na 1.000 zaposlenih radnika, koja je svakako vjerodostojniji pokazatelj jer anulira oscilacije u ukupnom broju radnika, situacija je daleko više na strani modela ONR_min.

Tako je očito kako je stopa ONR na 1.000 radnika u razdoblju 2008.-2012. primjenom konvencionalnih metoda smanjena za 27,26\%, dok je stopa ONR na 1.000 radnika u razdoblju 2013.2017. primjenom modela ONR_min smanjena za $134,2 \%$. Ovdje se govori o gotovo 5 puta većem smanjenju ozljeda na radu primjenom modela ONR_min u odnosu na konvencionalne metode zaštite na radu.

Žuto obojani dio grafikona, a koji prikazuje ukupnu stopu ONR na 1000 radnika po godinama, zorno oslikava snagu implementiranog modela ONR_min. Dok konvencionalne metode ZNR ostvaruju najbolje rezultate godinu-dvije od implementacije, da bi potom omogućile isključivo stagnaciju te u konačnici uz sve napore i povećanje stope ONR (2013. god.), uspješnost modela ONR_min od njegove implementacije na dalje je

\section{Broj ozlijeđenih na 1000 zaposlenih za godine od 2008.-2017.}

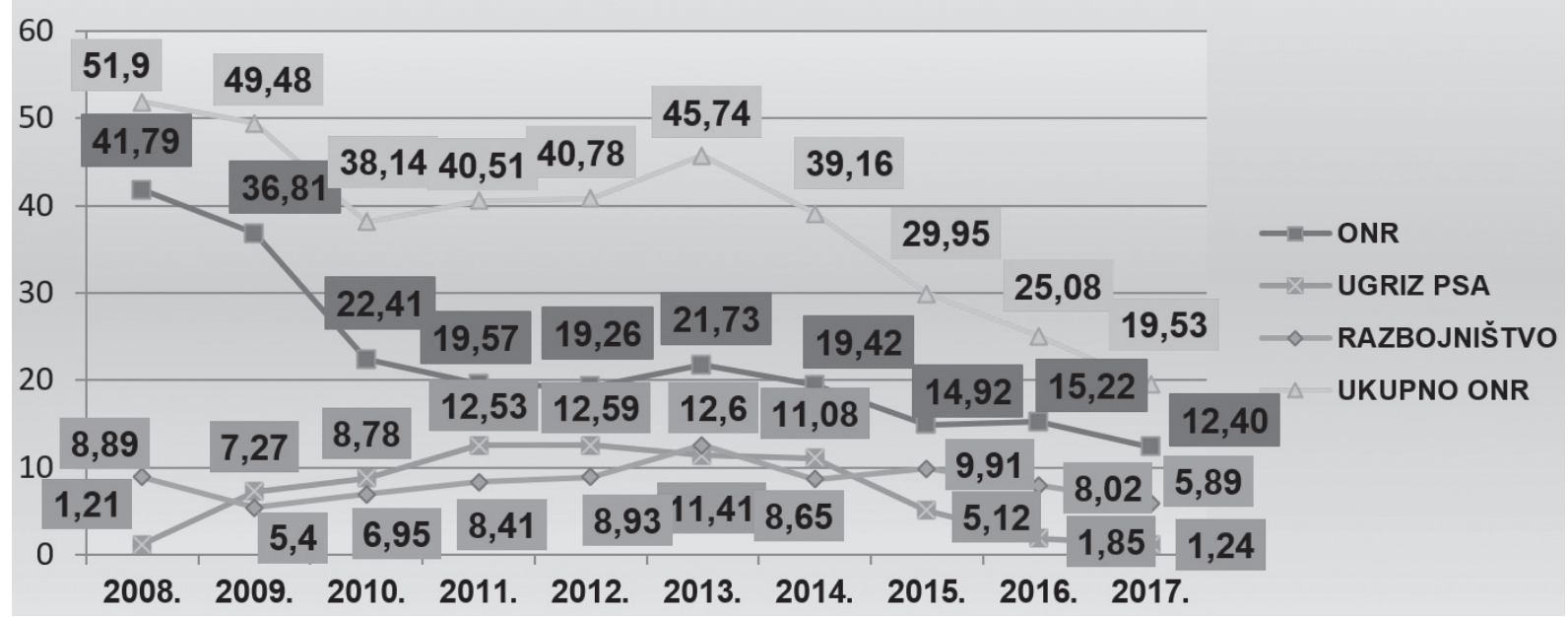

Slika 6. Stopa ONR na 1.000 radnika za razdoblje 2008.-2017.

Figure 6. ONR rate for 1,000 workers, 2008-2017 
gotovo linearna (pravocrtna u padu ukupne stope ONR) za sve promatrane godine.

Time se svakako potvrđuje i hipoteza postavljena u ovom istraživanju. Model ONR_min u promatranoj organizaciji Hrvatske pošte gotovo je 5 puta uspješniji u smanjenju ozljeda na radu od primjene struci poznatih i priznatih metoda zaštite na radu. Isto tako model ONR_min daje kontinuirane rezultate te njegova uspješnost ne jenjava za promatrane godine, već gotovo linearno smanjuje stopu ukupnog broja ONR. Naravno, ovo ne znači da se konvencionalne metode ne moraju koristiti jer je njihova primjena propisana zakonskim i podzakonskim odredbama i svakako se temelje na struci zaštite na radu, tisućama provedenih istraživanja i naporima desetaka tisuća stručnjaka ZNR u nas i svijetu. Međutim, ovaj model pokazao se iznimno uspješnim te je, uz primjenu konvencionalnih metoda, značajno pridonio smanjenju ozljeda na radu u poslovnom sustavu Hrvatske pošte. Kao i svaki organizacijski sustav model ONR_min podložan je čestim dopunama, revizijama i prilagodbama koje su povezane s većim ili manjim organizacijskim promjenama na razini cijelog poslovnog sustava te još više $s$ iskustvima iz prakse koje predmetni model donosi u svojoj svakodnevnoj uporabi.

\section{ZAKLJUČAK}

S obzirom na provedeno istraživanje i prikazane rezultate, može se zaključiti kako se promatrani model smanjenja ozljeda na radu ONR_min pokazao vrlo uspješnim u njegovoj organizacijskoj i realnoj provedbi na terenu. Kako se radi prvenstveno o organizacijskom modelu, njegova uspješnost ovisi o ozbiljnosti pristupu provedbe na terenu kao i o podršci Poslodavca. Model se mora sustavno pratiti od strane rukovodstva Službe zaštite na radu Hrvatske pošte, te je potrebno raditi redovite korekcije, a prema iskustvima i okolnostima s terena. Time se i nadopunjuje baza znanja kao temeljnog iskustva u okolnostima nastanka i preveniranja ozljeda na radu.

Isto tako financijski pokazatelji provedbe promatranog modela vrlo su značajni. Tako je 2017. god. Marijana Bađun provela znanstveno istraživanje o troškovima ozljeda na radu i profesionalnih bolesti u Republici Hrvatskoj. Prema ovom istraživanju ${ }^{33}$ ukupni troškovi po ozljedama na radu u Republici Hrvatskoj u 2015. god. (koje su platili Poslodavci za troškove liječenja, bolovanja, troškove po tužbama, administrativne troškove itd.) iznosili su 604,6 mil. kn. Prema podacima Hrvatskog zavoda za zaštitu zdravlja i sigurnost na radu ${ }^{34}$, u 2015. god. u Republici Hrvatskoj bilo je ukupno prijavljeno i verificirano 16.013 ozljeda na radu. To nam jasno pokazuje kako je prosječan trošak za Poslodavce po jednoj ozljedi na radu u 2015. god. u Republici Hrvatskoj iznosio točno: $37.756,82 \mathrm{kn}$. Naravno da se tu radi o prosjeku i da stvarni iznosi mogu jako varirati od ozljede do ozljede. No, ako se ovaj prosjek primijeni kao financijski benefit implementiranog modela ONR_min i smanjenja ukupnog broja ONR od njegovog uvođenja na početku 2014. do kraja 2017. god. govori se o ukupno 759 ONR manje u promatrane četiri godine. Drugim riječima, govori se o 28.657.426,38 kn uštede na prosječnim troškovima ozljeda na radu u Hrvatskoj pošti.

Hrvatska pošta kao Poslodavac prepoznala je ove napore te je po prvi puta u svoja financijska javna izvješća ugradila informaciju i o zaštiti na radu. Tako se u Godišnjem konsolidiranom financijskom izvješću HP-a za 2017. god. navodi sljedeće: „Kontinuiranim višegodišnjim aktivnostima smanjen je broj ozljeda na radu ponajprije kao rezultat modela terenskog nadzora svake ozljede na radu koji je uveden početkom 2014. godine. U 2017. godini evidentirano je 188 ozljeda na radu što znači da broj ozljeda kontinuirano pada i sada je najniži od 2008. god. i smanjen za 29,2 \% na tisuću zaposlenih u odnosu na 2016. god. Primjena navedenog modela dovela je do smanjenja posrednih i neposrednih troškova kompanije. ${ }^{135} \mathrm{Od}$ izrade ovog izvješća jedna ONR je naknadno priznata, pa je ukupan broj ONR u 2017. god. 189.

Iznosu od 28,5 milijuna kn uštede na prosječnom trošku ozljeda na radu u zadnje četiri godine treba pridodati i cijeli niz aktivnosti koje je Služba ZNR Hrvatske pošte preuzela od vanjskih izvođača poput: izrade Procjene rizika, izrade Procjena požarne ugroženosti, raznih osposobljavanja iz

\footnotetext{
${ }^{33}$ Bađun, 2017.

${ }^{34} \mathrm{http}: / / \mathrm{hzzzsr} . \mathrm{hr} / \mathrm{wp}$-content/uploads/2016/11/ANALIZA_ ONR_2015.pdf

${ }^{35}$ https://www.posta.hr/UserDocsImages/posta/Dokumenti/ Godisnjeizvjesce\%202017.HPddkonsolidirano.pdf
} 
područja ZNR i ZOP itd., a kroz koje su aktivnosti također ušteđeni ozbiljni financijski iznosi. Ovdje prikazane uštede višestruko premašuju ukupne troškove za plaće, edukacije i druge izdatke za cjelokupnu Službu ZNR Hrvatske pošte na godišnjoj razini (26 stručnjaka ZNR), a čime se pokazuje kako je sustav zaštite na radu Hrvatske pošte (te posljedično i sustav na razini Države) svrsishodan, opravdan i svakako dugoročno isplativ za Poslodavce.

\section{LITERATURA}

About the Business Process Model and Notation specification version 2.0. Dostupno na: https://www.omg.org/spec/BPMN/2.0/Pristupljeno: 6.11. 2018.

Analiza ONR u 2015. god. Dostupno na: http://hzzzsr.hr/wp-content/uploads/2016/11/ ANALIZA_ONR_2015.pdf. Pristupljeno: 21.11. 2018.

Bađun, M.: Troškovi ozljeda na radu i profesionalnih bolesti u Hrvatskoj. Arhiv za higijenu rada i toksikologiju, 68, 2017., 1, 66-73.

Biličić, M.: Metoda slučaja u znanosti i nastavi. Pomorstvo, 19, 2005., 217-228.

Bognolo, D. \& Ferhatović, M.: Modeli evidencija u funkciji smanjenja ozljeda vatrogasaca. Vatrogastvo i upravljanje požarima, 3, 2013., 1, 55-69.

Bradić, Đ. \& sur.: Ozljede radnika u poljoprivrednoj proizvodnji. Arhiv za higijenu rada i toksikologiju, 35, 1984., 2, 193-197.

Brumec, J. \& Brumec, S.: Modeliranje poslovnih procesa, KORIS d.o.o. za informatički inženjering, Zagreb, 2016.

Dujanić, M.: Upravljanje promjenama u poduzeću. Zbornik radova Ekonomskog fakulteta u Rijeci: časopis za ekonomsku teoriju i praksu, 22, 2004., 1, 39-51.

Grupa autora: Analiza ozljeda na radu po djelatnostima. Interni dokument. Hrvatski zavod za zadravstveno osiguranje, Zagreb, 2013.
Hrvatska enciklopedija. Dostupno na: http:// www.enciklopedija.hr/natuknica.aspx?id=49722, Pristupljeno: 22.10. 2018.

Godišnje konsolidirano financijsko izvješće: Hrvatska pošta. Dostupno na: https://www.posta. hr/UserDocsImages/posta/Dokumenti/Godisnje_ izvjesce_\%202017._HP_dd_konsolidirano.pdf. Pristupljeno: 21.11.2018.

Kolektivni ugovor za radnike HP - Hrvatske pošte d.d. HP d.d. - Hrvatski sindikat pošte - Republički sindikat radnika Hrvatske, Zagreb, 8.12. 2017.

Košiček, M.: Neurotična ličnost kao uzrok ozljede pri radu. Arhiv za higijenu rada i toksikologiju, 4, 1953., 1, 62-65.

Kovač, C.: Povjerenik radnika za zaštitu na radu u HP - Hrvatskoj pošti d.d. Sigurnost, 59, 2017., 4, 399-403.

Kovač, C.: Unapređivanje sustava zaštite na radu i radnička participacija. M\&S 13. Ohrid: European Society of Safety Engenners, 2018.

Kozina, B.: Profesionalna izloženost i principi zaštite od ubodne ozljede u operacijskoj dvorani. Sestrinski glasnik, 21, 2016., 1, 49-52.

Mance, I. \& sur.: Pravilnik o zaštiti na radu. Hrvatska pošta d.d., 2013.

Mance, I. \& sur.: Prevencija ugriza pasa u djelatnosti univerzalnih poštanskih usluga. Sigurnost, 57, 2015., 1, 11-24.

MS Access 2008. Dostupno na: https://products. office.com/hr-hr/access. Pristupljeno: 11.12.2018.

Nacionalni program zaštite zdravlja i sigurnosti na radu za razdoblje 2009. - 2013. god. Zagreb: Ministarstvo gospodarstva, rada i poduzetništva.

Nyström, A.: Occupational injuries caused by electricity. Arhiv za higijenu rada i toksikologiju, 1, 1950., 3, 283-290.

Pavlič, M. \& Markič, M.: Ozljede na radu u Republici Sloveniji od 1960. do 2008. Sigurnost, 52, 2010., 1, 1-17. 
Pupavac, D. \& sur.: Statistička analiza ozljeda i ocjena na radu u Republici Hrvatskoj. Sigurnost, 60, 2018., 3, 225-233.

Sakcinski, I. K.: Acta Croatica (Listine Hrvatske). Narodna tiskarnica dra. Ljudevita Gaja, Zagreb, 1863.

Thompson, W. G.: The Occupational Diseases: Their Causation, Symptoms, Treatment, and Prevention. D. Appelton and Co., New York \& London, 1914.

Vučinić, J. \& Ivančić, Z.: Ozljede na radu u graditeljstvu Karlovačke županije. Građevinar, 55, 2003., 12, 735-739.
Yammer. Microsoft Office, Dostupno na: https://products.office.com/hr-hr/yammer/ yammer-overview, Pristupljano: 6.11.2018.

Yanar, B. \& sur.: Occupational Health and Safety Vulnerability of Recent Immigrants and Refugees. International Journal of Environmental Research and Public Health, 15, 2018., 1, 1-16.

Zakon o obveznom zdravstvenom osiguranju. Dostupno na: https://www.zakon.hr/z/192/Zakon-o-obveznom-zdravstvenom-osiguranju, Pristupljeno: 22.10. 2018.

Zaštita na radu. Dostupno na: https://www.zastitanaradu.hr/Pristupljeno: 12.11.2018.

\title{
MODEL PROPOSING HOW TO REDUCE OCCUPATIONAL INJURIES OF CROATIAN POSTAL WORKERS
}

\begin{abstract}
SUMMARY: The aim is to develop, model and implement a system guaranteeing fewer occupational injuries of postal workers in Croatia. The paper presents the plan (Gantt chart) for modelling and introduction of the system in Croatian postal service using the method of modelling suitable for the theoretical development of the ONR_min system. Furthermore, an analysis was conducted as to its suitability based on the data showing occupational injuries of Croatian postal workers prior to its introduction in 2014 and following up through to 2017. Several case studies indicate the actual effects of the model with financial indicators and savings given in conclusion.
\end{abstract}

Key words: reducing occupational injuries, model ONR_min, Croatian postal service, safety at work

Original scientific paper

Received: 2018-11-22

Accepted: 2019-05-29 